\title{
Employment effects of language training for unemployed immigrants
}

\author{
Julia Lang ${ }^{1}$
}

Received: 4 November 2019 / Accepted: 10 February 2021 / Published online: 16 March 2021

(C) The Author(s) 2021

\begin{abstract}
Proficiency in the host country's language is an important factor for the successful labor market integration of immigrants. In this study, I analyze the effects of a language training program for professional purposes on the employment opportunities of participants in Germany. I apply an instrumental variable approach and exploit differences in lagged local training intensities. Bivariate probit estimates show that 2 years after the program started, the employment probability of immigrants who were unemployed in 2014 and participated in the program had increased by more than nine percentage points as a result of language training.
\end{abstract}

Keywords Language training $\cdot$ Migration $\cdot$ Integration $\cdot$ Employment

JEL Classification J24 · J61 · J68

\section{Introduction}

The social and economic integration of immigrants is a major challenge for migration policies. In most OECD countries, the labor market performance of immigrants lags behind that of the native-born population (OECD 2016). A crucial factor shaping the career success of immigrants is the acquisition of language skills in the destination country's language. Language proficiency is necessary to obtain information about jobs and to be able to apply for a job. Moreover, many jobs - especially skilled jobsrequire language skills in the host country's language so that workers can communicate with supervisors, peers, customers, and business partners. Immigrants who speak the local language are more likely to find a job and more productive on the job (Chiswick and Miller 2014).

Responsible editor: Klaus F. Zimmermann

Julia Lang

julia.lang@iab.de

1 Institute for Employment Research, IAB, Regensburger Str. 104, 90478 Nuremberg, Germany 
In this study, I analyze a language training program for unemployed immigrants in Germany and estimate employment effects for participants in 2014 up to 2 years after the start of the course. This language course is unique in that it focuses on professional aspects. Moreover, some of its features, like application training and work placements, go beyond the contents of a pure language course and are comparable to active labor market policy (ALMP) measures that bring participants into contact with the labor market.

Numerous studies show that language skills are important for immigrants' labor market success. Chiswick and Miller (2014) provide a comprehensive overview of research findings from different countries. Most studies analyze the effects of language proficiency on earnings and find a positive impact (e.g., Bleakley and Chin 2004; Chiswick and Miller 1995; Miranda and Zhu 2013; Ferrer et al. 2006; Budría and Swedberg 2015; Di Paolo and Raymond 2012; Chiswick 1998; Dustmann 1994; and Dustmann and van Soest 2001, 2002). Other studies also consider other labor market outcomes, such as employment (Dustmann and Fabbri 2003; Yao and van Ours 2015) and hours of work (Yao and van Ours 2015).

Given that the vast majority of studies find positive effects of language proficiency on immigrants' labor market success, formal language training could be a helpful means to accelerate integration into the host country's labor market. In contrast to the extensive literature on the language skills of migrants and the clear evidence for positive labor market effects, there is less evidence on the role of formal language training, and the existing results are mixed. Hayfron (2001) analyzes the impact of language training for immigrants in Norway and finds it improves language skills but has no effect on earnings. Clausen et al. (2009) use Danish data on different active labor market programs and language courses for newly arrived immigrants and show that the improved language proficiency of language course participants has a positive impact on the hazard rate to employment. Sarvimäki and Hämäläinen (2016) find positive earnings effects of the introduction of integration plans for unemployed immigrants in Finland, which, among other things, involved immigrants spending more time in language courses. Åslund and Engdahl (2018) analyze performance bonuses in immigrant language training in Sweden and find no effects on average student achievement but positive effects for specific groups. Lochmann et al. (2019) show that very basic language training provided in France increases the labor force participation of immigrants but has no impact on employment or even on language proficiency.

Some studies attribute the observed absence of positive effects of language training on employment (or earnings) to courses covering a very basic level of language proficiency (Lochmann et al. 2019). Moreover, many previously adopted integration measures, such as language courses, have not particularly been aligned with the needs of the labor market (OECD 2017). One exception is the language program I evaluate here. I contribute to the literature by estimating causal effects of a unique language training program with a strong focus on employment-related topics. The program teaches job-specific vocabulary and applications (e.g., writing applications or emails to business partners) of the German language. The language program ends with an internship, during which the participants come into contact with the job market and can directly apply their newly acquired language skills. The internship also provides an opportunity to establish contact with potential employers (BAMF 2013). 
Evidence on other ALMP programs shows that programs that are closely linked to the labor market, such as wage subsidies and work experience programs, are especially effective in improving immigrants' labor market prospects (Rinne 2013; Butschek and Walter 2014). For example, Clausen et al. (2009) find that among different active labor market programs for immigrants in Denmark, only wage subsidies increase the hazard rate into regular employment. Thus, combining language training with labor market contact could make the language program studied here especially effective. ${ }^{1}$

For the analysis, I use high-quality administrative data from the German Federal Labor Agency (FEA). In addition to information on participation in language training, the data include detailed information on the employment and unemployment histories of workers and their individual characteristics. As language skills are not observed in my data, I apply an instrumental variable approach to address unobserved heterogeneity. I use the exogenous variation in local language training intensity at the regional level, which is the job center level in my case. ${ }^{2}$ Differences in local language training intensities can be caused by differences in local labor market conditions but also by differences in job centers' policy styles. The underlying premise of this approach is that local decision makers at job centers have broad discretionary power in regard to the implementation of different labor market programs. As there are no concrete assignment rules, local job centers can choose their individual mix of programs, which is partly determined by their individual experiences and preferences. Policy styles vary between job centers and affect the probability of being assigned language training but are exogenous to jobseekers' labor market outcomes. After controlling for regional- and individual-level confounders, residual variation in language training intensity reflects the policy styles of job centers. Several studies have exploited regional variation in the policy styles of employment agencies and partly used an instrumental variable approach to analyze the effects of several labor market programs (Frölich and Lechner 2010; Lechner et al. 2013; Markussen and Røed 2014; Boockmann et al. 2014; Dean et al. 2015; Caliendo et al. 2017; Eppel 2017; Dauth 2020). Following this approach, I identify causal effects by addressing selection into the studied program based on unobservable characteristics.

I find that the language training program for professional purposes examined here increases participants' employment probability by more than 9 percentage points after 2 years. In comparison to results found in other studies on language training, this is a highly positive effect, which may be explained by the program's strong orientation towards the needs of the labor market and its practice-oriented design, which includes an internship. Although there is no significant effect on cumulated employment and earnings 2 years after the start of the program because of a strong lock-in effect during

\footnotetext{
${ }^{1}$ Two studies also consider language training for professional purposes but may fail to identify causal effects. For refugees in Germany, Brücker et al. (2016) find a positive correlation between language training and employment probability. Walter et al. (2014) apply a matching approach to estimate the effects of language training. As the language skills of immigrants are not observed in their data, they argue that using a wide range of observable characteristics should capture differences in the initial language proficiency of participants and nonparticipants. They find no effect on the employment chances of participants up to 18 months after the start of the program. However, if language skills are not fully reflected by observable variables, the estimated effects will be biased.

${ }^{2}$ Participants of the language course for professional purposes must either be registered as job seeking with a local employment agency or with a local job center. As the large majority of participants in the program are registered with job centers, I limit my analysis to this group. See Section 2 for more details.
} 
language training, the analysis shows that participants are more likely to find stable and substantial employment. Subgroup analyses show that the early provision of language programs benefits the labor market integration of immigrants.

The paper is organized as follows. Section 2 describes the institutional setting considered, followed by a description of the data used for the empirical analysis and of descriptive statistics provided in Section 3. Section 4 presents the econometric approach employed. Section 5 presents the empirical results and Section 6 concludes.

\section{Institutional setting}

Despite a long history of immigration, it was not until the 2000s that Germany acknowledged that it is a country of immigration. The Immigration Act of 2005 fundamentally reformed the immigration law and established integration as a government responsibility. Since then, immigration laws have been liberalized, at least for qualified migrants. The EU Blue Card, which was introduced in 2012, enables skilled workers from non-EU countries to work in the EU, whereas, due to the freedom of movement, citizens from EU member states face no restrictions on their access to employment or self-employment in Germany.

To facilitate the social and economic integration of asylum seekers with good prospects of remaining in the country, barriers to entry into the labor market have been gradually removed in recent years. After staying in Germany for 3 months, asylum seekers are allowed to work with the approval of the Federal Employment Agency.

If they have a work permit, similar to the situation in many other OECD countries, in Germany, foreign-born residents are more often affected by unemployment than nativeborn residents (OECD 2016). In 2014 - the year I observe the participants - the unemployment rate of foreign-born residents was $14.3 \%$ compared to the unemployment rate of native-born residents of only $6.0 \%{ }^{3}$ To integrate unemployed immigrants into the German labor market, the German Federal Employment Agency (FEA) and German Federal Office for Migration and Refugees (Bundesamt für Migration und Flüchtlinge, BAMF) work closely together. Both institutions are responsible for several different measures designed to help immigrants with a work permit to enter the labor market. While the FEA mainly provides different active labor market policy (ALMP) programs such as training, wage subsidies or subsidized employment schemes, which often are not specifically targeted at immigrants, the BAMF offers different language programs. In addition to introduction programs - the so-called integration courses introduced in 2005- the BAMF is responsible for a language training program that provides language skills for professional purposes started in 2009 called the ESFBAMF program. ${ }^{4}$ This program is intended to help immigrants achieve a high enough level of language proficiency to enter the German labor market. At local employment agencies or job centers, caseworkers responsible for jobseekers can assign them to a language course when jobseekers' German skills are insufficient. Although the

\footnotetext{
${ }^{3}$ Statistik der Bundesagentur für Arbeit. The most current figures for 2019 show similar differences (foreignborn: $12.3 \%$, native born: $4.0 \%$ ).

${ }^{4}$ The program was discontinued in 2017 , but to a large extent, its contents were transferred to the vocational German language promotional program of the BAMF, a program which started in July 2016 and became a standard instrument of the Federation's language promotion.
} 
proposal to participate in the course may also come from the jobseeker, the final decision on assignment to language training is made by the caseworker. However, the final decision on participation lies with the educational institution, which can exclude a person who does not pass the placement test (Walter et al. 2014).

There are several preconditions for participating in the program. First, potential participants must have basic German skills but not enough language proficiency to find a job. To participate in language training for professional purposes, a language level of at least A1 (beginner) under the Common European Framework of Reference for Language is required: this level is regularly achieved through a prior integration course. Most immigrants are entitled to participate in such an integration course. However, a local immigration office or job center can also oblige clients with particular integration needs to participate. The integration course primarily focuses on language training (600 lessons). The course ends with a final examination, and participants pass the course by achieving a language level of up to B1 (intermediate level) under the Common European Framework of Reference for Languages. Between 2009 and 2016, approximately $56 \%$ of the participants finishing the course passed the language examination with a language level of B1, approximately $35 \%$ completed the course with a lower language level of A2 (elementary level), and only approximately $9 \%$ did not reach this level (BAMF 2017). Thus, most of those finishing an integration course have basic language skills, which, however, may not be sufficient to enable the participants to find a job, possibly requiring them to pursue additional language training such as the language training program for professional purposes.

Potential participants of the language course for professional purposes must be registered as jobseekers and can receive either unemployment benefits through the unemployment insurance benefits system or welfare benefits. Unemployed people are only eligible for unemployment benefits after a period of contributory employment. They regularly receive unemployment benefits for up to 1 year and are registered with an employment agency. Unemployed people who are not eligible for unemployment benefits are supported by job centers and receive welfare benefits. The majority of participants in the program are welfare benefit recipients and are registered with job centers. Moreover, potential participants must have a migration background, but nationality and the date of immigration are irrelevant. Finally, they must have fulfilled the mandatory schooling requirements.

The language training program has different components: German language training, professional skills building, and work placements. The language training is designed to provide language skills required to, for example, write job applications or communicate with customers or clients and colleagues. Professional skills building involves specialized teaching such as job application training, training in vocational issues, or IT training. Finally, work placements and visits to firms are intended to help participants learn more about a certain profession. Thus, participants not only learn how to communicate in German but also come into direct contact with the labor market, enabling them to apply their learned language skills in a professional environment. Experience reports from participants show that German lessons play an important role, as initial language skills are often not sufficient for employment in the German labor market. However, the internship component is also very important. Some participants report that after the internship, they received an offer for a job or for apprenticeship training directly from the employer with whom they completed the internship (BAMF 
2013). The program includes up to 730 lessons, and the whole program usually involves 6 months of full-time study. Alternatively, the program takes 12 months of part-time study to complete. On successfully completing the course, participants obtain a certificate of attendance.

\section{Data and descriptive statistics}

\subsection{Data and sample selection}

For the empirical analysis, I use administrative data provided by the Institute for Employment Research (IAB). The main data are drawn from the Integrated Employment Biographies (IEB), which is a merged database combining the individual records of different administrative sources of the FEA. The records contain information on all employment episodes (except for self-employment), job search episodes, receipt of transfer payments made during unemployment, and episodes of program participation. Moreover, the data cover a wide range of individual characteristics and provide information on job types and wages for employment periods (see Dorner et al. 2010 for more information on the IEB).

Moreover, I use supplementary data from employment biographies collected retrospectively during meetings with jobseekers and caseworkers (Werdegangshistorik, WGH). These data include information on participation in one of the language courses provided by the BAMF, in integration courses and in language training for professional purposes. Furthermore, they may include information on episodes with missing data from the IEB such as episodes of self-employment or parental leave. When no WGH information on episodes with missing data in the IEB is available, this can represent periods without participation in the labor market or may denote that workers have returned to their home countries or emigrated to another country (and may have returned to Germany at a later date).

The WGH data are also advantageous in that they may provide information on education and employment abroad. As a considerable share of individuals in the sample are observed in the IEB only for a short period, this additional information on prior employment in foreign countries (before individuals are observed in the IEB) can be helpful for modeling previous employment histories.

Since the data are based on persons' unemployment and employment notifications, my sample only includes immigrants who already have a work permit and are active in the German labor market. This is not a limitation in this case, as only this group of immigrants is eligible for the language training program.

None of the data includes information on the migration backgrounds or home countries of the individuals, but information on nationality is included in the IEB. Thus, in my empirical analysis, I use this information as a proxy for the home country. If an individual has German citizenship at the analysis point of time, I go back in time and use the modus of all spells with non-German nationality as a proxy for the home country of an individual with a migration background. Nationality plays no role in eligibility, and approximately $11 \%$ of all participants included in the data have spells with German citizenship only. These can be second-generation migrants with German citizenship or ethnic German immigrants from Eastern European countries acquiring 
their German citizenship upon entering Germany (and thus who have always had German citizenship according to the IEB data).

The data also do not include any information on the date of migration. As the time since migration is an important determinant of language skills, I use the duration from the first observed spell in the IEB data as a proxy for length of stay in Germany. This variable reflects the duration since entry into the German labor market and is correlated with the elapsed time since migration. Moreover, I generate a dummy variable that equals one when the age at entry in the German labor market (age at first observation in the administrative data) is less than 30 years.

For my analysis, I use the total population of participants who started language training for professional purposes in 2014. I can follow those in the sample to the end of 2016. Thus, with a regular course duration of 6 months, I observe the participants for at least 1.5 years after they finished the language training and 2 years after they started the course. I choose the start of the training as the starting point for my estimations and report the results of the outcome variable for up to 2 years after this point in time.

In addition to the participants' data, I draw a random sample of non-participants with at least one period of non-German citizenship in the data to identify those with a migration background. To make the participants and non-participants comparable, I exclude all participants with German nationality only. Although I know that the participants have a migration background and a need for language training even if I only observe German citizenship throughout the observation period, it is impossible to distinguish between those with and without a migration background for nonparticipants with German citizenship only.

I construct monthly data, and for the non-participants with multiple months in unemployment, I randomly choose 1 month as a starting point for the analysis. The IEB covers variables indicating whether a jobseeker is supported by an employment agency (and probably receives an unemployment benefit) or by a job center (and receives welfare benefits). As the vast majority of the individuals (more than $80 \%$ of the participants and non-participants) are clients of job centers, I focus on this group of unemployed people. I also exclude individuals who are in employment or participating in any active labor market policy measure or integration course at the starting date and individuals with missing information on important covariates.

The data indicate that the participants migrated later than the non-participants did, as the mean duration since the first observation in the raw data is more than 169 months for the non-participants and thus much longer than that for the participants ( 80 months). To make participants and non-participants more comparable with respect to their migration history, I remove all individuals whose first spell in the IEB data started more than 25 years ago and stratify the estimation sample with respect to that variable. ${ }^{5}$

\footnotetext{
${ }^{5}$ I divide the sample into 20 strata. Cutoff points are chosen according to the distribution of the variable for the treatment group. Each of the 20 strata includes approximately 500 treatment group observations. Within each stratum, I randomly choose 3 control observations (the maximum in the stratum with the fewest control observations) for the estimation sample. The distribution of the variable indicating the duration since the first observation in the data can be found in Appendix Figure 2. The distribution for control observations is very different to the treatment group in the raw data but very similar in the final stratified dataset. In the final sample, the mean duration since the first observation in the IEB data is approximately 77 months. This is close to the mean duration for participants in the raw data ( 80 months), as I mainly lose observations for nonparticipants when restricting the sample to individuals whose first spell in the IEB data started more than 25 years ago.
} 
Due to the definition of my instrument, I do not include individuals with a (hypothetical) language training start in January 2014 in the estimation sample (see Section 4.2). However, information on these participants is used to construct the instrument. The final estimation sample includes 35,431 individuals who were unemployed at least once between February and December 2014. In total, 8968 of them are participants.

In addition to individual-level data, I include variables of the regional level (district or job center level) from the Statistics of the German Federal Employment Agency and the German Federal Statistical Office. These data are used to control for differences in local labor market conditions and cover, e.g., the unemployment rate of natives and foreign-born individuals, the GDP per capita, the age structure of the population, and the number of unemployed persons per vacancy. ${ }^{6}$

\subsection{Descriptive statistics}

Table 1 presents the mean values of selected socio-demographic variables for the final estimation sample. ${ }^{7}$ At $38 \%$, the share of men of the participants is much lower than that of the non-participants $(45 \%)$. Moreover, participants are on average almost 3 years older than the non-participants are. With regard to education variables, the language training participants seem to represent a positive selection of the unemployed immigrants. They have more advanced schooling degrees and more often have a vocational or university degree. A total of $30 \%$ of the participants come from other EU countries, and 25\% come from Near Eastern and Middle Eastern countries whereas the second most important region of origin among non-participants (after EU countries) is Turkey.

Although the socio-demographic variables indicate that the participants have more favorable characteristics with regard to education, Table 1 also shows that they do not seem to perform better in the labor market. Both during the last year and the prior 5 years before the (hypothetical) start of the program, they spent less time in employment than the non-participants. The participants were also unemployed longer and received unemployment benefits for more days in the past. However, participants spent more days in employment outside Germany over the last 5 years. As the sample is stratified with respect to the duration since the first observation in the data, these differences are not caused by differences in the time of entry into the German labor market. Nonparticipants seem to be somewhat better integrated into the German labor market. It may also be that qualified immigrants try to find a suitable qualified job, which takes longer and can lead to longer periods of unemployment in the data. Finally, for language training participants, the share of individuals who had taken a previous integration course is $65.8 \%$, which is much higher than that for the non-participants $(23.9 \%)$.

Finally, the lower part of Table 1 shows mean values for the outcome variable employment subject to social security contributions. Six months after the (hypothetical) start of the program (at the regular end of the course), the share of employed participants $(6.0 \%)$ is lower than the share of employed non-participants (13.6\%). After 2

\footnotetext{
${ }^{6}$ For a complete overview of the regional variables used, see Appendix Table 11.

${ }^{7}$ For the mean values of all control variables used in the estimations, see Appendix Table 11.
} 
Table 1 Mean values of selected individual variables

\begin{tabular}{|c|c|c|}
\hline & Participants & Non-participants \\
\hline \multicolumn{3}{|l|}{ Socio-demographic characteristics } \\
\hline Male & 0.376 & $0.449 * * *$ \\
\hline Age (in years) & 36.101 & $33.318 * * *$ \\
\hline \multicolumn{3}{|l|}{ School-leaving degree } \\
\hline No secondary degree & 0.223 & $0.257 * * *$ \\
\hline Lower/middle sec. degree & 0.408 & $0.529 * * *$ \\
\hline Higher secondary degree & 0.369 & $0.214 * * *$ \\
\hline \multicolumn{3}{|l|}{ Vocational degree } \\
\hline No vocational degree & 0.625 & $0.729 * * *$ \\
\hline German/unknown voc. degree & 0.057 & $0.105^{* * *}$ \\
\hline German/unknown university degree & 0.030 & $0.025 * * *$ \\
\hline Foreign vocational degree & 0.132 & $0.077 * * *$ \\
\hline Foreign university degree & 0.156 & $0.064 * * *$ \\
\hline \multicolumn{3}{|l|}{ Region of origin } \\
\hline EU countries & 0.295 & $0.329 * * *$ \\
\hline Turkey & 0.108 & $0.204 * * *$ \\
\hline Russia & 0.065 & $0.036^{* * *}$ \\
\hline Other European countries & 0.071 & $0.109 * * *$ \\
\hline North Africa & 0.035 & 0.035 \\
\hline Other African countries & 0.069 & $0.045^{* * *}$ \\
\hline Near/Middle East & 0.246 & $0.177 * * *$ \\
\hline Other Asian countries & 0.076 & $0.046^{* * *}$ \\
\hline America, Australia & 0.036 & $0.019 * * *$ \\
\hline \multicolumn{3}{|l|}{ Labor market history } \\
\hline \multicolumn{3}{|l|}{ Labor market history 1 year prior to (hypothetical) start of training } \\
\hline Days in employment & 25.421 & $33.825^{* * *}$ \\
\hline Days in job search & 294.426 & $246.220 * * *$ \\
\hline Days with unemployment benefit receipt & 18.444 & $13.908 * * *$ \\
\hline Days with unemployment benefit II receipt & 298.939 & $252.726 * * *$ \\
\hline \multicolumn{3}{|c|}{ Labor market history 5 years prior to (hypothetical) start of training } \\
\hline Days in employment & 161.711 & $169.501^{*}$ \\
\hline Days with job search & 932.607 & $826.067 * * *$ \\
\hline Days with unemployment benefit receipt & 40.176 & $37.728 *$ \\
\hline Days with unemployment benefit II receipt & 940.603 & $842.649 * * *$ \\
\hline Days in employment in foreign country & 135.151 & $87.165^{* * *}$ \\
\hline Integration course in the past (yes $=1$ ) & 0.658 & $0.239 * * *$ \\
\hline \multicolumn{3}{|l|}{ Outcome } \\
\hline Employed 6 months after (hypothetical) start of training & 0.060 & $0.136^{* * *}$ \\
\hline Employed 24 months after (hypothetical) start of training & 0.271 & $0.245^{* * *}$ \\
\hline$N$ & 8968 & 26,463 \\
\hline
\end{tabular}

Source: IEB V12.01.00, WGH V01.01.00-201604

Note: All numbers are shares unless otherwise indicated. $* / * * * * * *$ indicate significant differences of mean values between participants and non-participants at the $10 \% / 5 \% / 1 \%$ level 
years, $27.1 \%$ of the former language training participants have found a job, which is slightly higher than the share of employed individuals among the non-participants $(24.5 \%)$.

The mean values of selected regional control variables for participants and nonparticipants are shown in Table 2. In comparison to non-participants, participants live in more densely populated regions with lower GDP per capita values, higher unemployment rates, and higher numbers of unemployed persons per vacant job. However, the share of foreign-born individuals is lower in these regions as well as the share of low-skilled individuals among the foreign-born and the share of unemployed who participate in active labor market policy (ALMP) programs, e.g., training schemes or wage subsidies. There are also some differences with respect to the intensity of different ALMP measures for the foreign-born unemployed. ${ }^{8}$

\section{Econometric approach}

\subsection{Local treatment intensity as an instrumental variable}

Although I have very rich data that cover not only a variety of socio-demographic characteristics but also the detailed employment histories of individuals and variables on the regional level, my data provide no information on language skills. To identify the effect of language training on employment, I estimate the following binary probit model:

$$
P\left(Y_{i}=1\right)=\phi\left(X_{i} \beta+R_{j} \gamma+T_{i} \theta+u_{i}\right)
$$

where $i$ denotes the individual and $j$ denotes the job center. $Y_{i}$ is the binary outcome variable employment subject to social security contributions (regular employment), $X_{i}$ is a vector of individual covariates, $R_{j}$ is a vector containing the regional control variables, and $T_{i}$ is a dummy variable indicating participation in language training. Every month after the (hypothetical) start of the course, I measure employment up to 24 months after treatment start.

Unobserved language proficiency and other unobserved factors such as motivation are correlated both with the employment opportunities of immigrants and with participation in language training:

$$
\operatorname{Cov}\left(T_{i}, u_{i} \neq 0\right)
$$

As those who need language training should also have worse employment prospects, the effect is likely to underestimated if I cannot sufficiently control for language skills. However, other unobserved variables may work in the other direction. For example, more motivated workers are more likely to find a job and may also be more willing to participate in language training. To overcome endogeneity problems and estimate

\footnotetext{
${ }^{8}$ The ALMP intensities are calculated the same way that language training intensity is calculated (see Section 4.2). These measures are part of the regular active labor market policy measures of the Federal Employment Agency and not specifically designed for immigrants and do not include language courses.
} 
Table 2 Mean values of selected regional variables

\begin{tabular}{lll}
\hline & Participants & Non-participants \\
\hline Unemployment rate of foreign-born & 19.495 & $18.654^{* * *}$ \\
Unemployment rate of native-born & 8.849 & $8.220^{* * *}$ \\
Share of foreign-born among unemployed & 0.341 & $0.357^{* * *}$ \\
Share of foreign-born in labor force & 0.158 & $0.162^{* * *}$ \\
Share of low-skilled among foreign-born & 0.560 & $0.567^{* * *}$ \\
Number of unemployed per vacancy & 7.479 & $6.789^{* * *}$ \\
Share of unemployed entering ALMP programs & 0.060 & $0.062^{* * *}$ \\
GDP per capita & $42,257.76$ & $43,025.41^{* * *}$ \\
Population density & 2082.819 & $1784.332^{* * *}$ \\
Intensity of ALMP measures for foreign-born & & \\
Placement budget & 0.207 & $0.211^{*}$ \\
Activation/integration measures (provider) & 0.038 & $0.039^{* * *}$ \\
Activation/integration measures (employer) & 0.191 & $0.203^{* * *}$ \\
Training & 0.045 & $0.043^{* * *}$ \\
Wage subsidies & 0.016 & $0.015^{* *}$ \\
Job creation scheme & 0.039 & $0.038^{* *}$ \\
$N$ & 8,968 & 26,463 \\
\hline
\end{tabular}

Source: IEB V12.01.00, WGH V01.01.00-201604. Statistics of the German Federal Employment Agency; German Federal Statistical Office. Own calculations

Note: $* / * * * * * *$ indicate significant differences of mean values between participants and non-participants at the $10 \% / 5 \% / 1 \%$ level

consistent effects, I apply an instrumental variable approach. Therefore, I must find an instrument $Z$ that affects the treatment probability of an individual but not the outcome of interest. Then, the first-stage estimation of the two-stage least squares estimator is written as follows:

$$
P\left(T_{i}=1\right)=\phi\left(Z_{i} \delta+X_{i} \alpha+R_{j} \pi+\varepsilon_{i}\right) .
$$

I argue that the local treatment intensity is an appropriate instrument. To prevent the participants from directly contributing to their respective instrument values, I use the lagged values of the monthly treatment intensity as an instrument. To calculate the job center-specific lagged monthly treatment intensity for month $t=2, \ldots, 12$ in 2014, I divide the number of participants at job center $j$ in month $t-1$ by the average number of foreign-born unemployed people registered with job center $j$ in month $t^{-1}$ :

$$
Z_{j t}=\frac{N \text { participants }_{j t-1}}{N \text { unemployed foreign } \text { born }_{j t-1}} .
$$

As I only have data on the number of individuals entering the program in 2014, I cannot calculate the lagged instrument for participants in January and thus exclude them from the main estimations. The mean lagged monthly language training intensity 
of job centers in the sample is 0.008 with a maximum of 0.359 , and 430 of 2706 monthly job center observations (2804 individuals) in the sample have a language training intensity of zero.

As I control for local labor market conditions $R_{j}$ (and also for individual differences between clients), the instrument only reflects the remaining differences in job centers' policy styles. In the selection of different labor market programs, job centers have broad discretionary power, which is partly determined by their experiences and preferences. A caseworker who is responsible for unemployed individuals with migration backgrounds can adopt different ways to integrate them into the labor market. The possibilities depend on the chosen combination of policy used by the local job center. Different job centers use different strategies and focus on different types of ALMP programs. Some job centers may focus on rapid labor market integration by finding low-skilled jobs that do not require strong language skills while others may mainly assign the unemployed to regular ALMP programs and others may give priority to improving language skills. Walter et al. (2014) provide evidence for heterogeneous assignment practices at the job center level. Their interviews with providers of the language courses show that job centers in different regions with similar local labor markets and similar shares of immigrants used the program to very different extents.

Nevertheless, job centers, which use language training more intensely, may generally care more about unemployed immigrants or may be those with a better reputation and network and may provide also other services for this group more frequently. If this is the case, different measures used by job centers to reintegrate unemployed immigrants should be correlated with language training intensity and thus must be considered in the analysis. Table 2 shows that although there are significant differences between the participants and non-participants with respect to the use of different ALMP measures for the foreign-born unemployed, these differences are small, and three of six ALMP intensities are on average higher among the non-participants. Thus, job centers responsible for the language training participants do not seem to place more emphasis on supporting the foreign-born unemployed than those responsible for non-participants. All ALMP intensities are also included in the estimations in the following sections.

As I use a binary outcome variable and a binary endogenous treatment variable, I apply a bivariate probit model to estimate the effects of participation in language training on employment probability with clustered standard errors at the job center level. Another approach to estimating causal effects with such a model involves disregarding the binary structure of the outcome and treatment variable and using a linear instrumental variables estimator. In this case, one does not estimate the average treatment effect but the local average treatment effect (Imbens and Angrist 1994). Chiburis et al. (2012) show that for a model with covariates or a low or high share of treated individuals, the bivariate probit model usually outperforms the linear IV.

\footnotetext{
${ }^{9}$ Appendix Table 11 shows the mean values of for monthly job center observations with low and high training intensities (split at the median) separately. The differences mostly go in the same direction as the differences between participants and non-participants, but are less pronounced, especially in the socio-demographic characteristics.
} 


\subsection{Plausibility of the instrumental variable conditions}

To be a valid instrument, local residual training intensity must be correlated with language training (relevance, $\operatorname{cov}(Z, T \mid X, R) \neq 0$ ) and, other than through training, must not affect the outcome variable employment (exogeneity, $\operatorname{cov}(Z, u)=0)$.

The relevance of the instrument can be seen from the first-stage results, which are reported and discussed in Section 5 where I present the results of the empirical analyses.

As a second assumption, the instrument must not have a direct impact on the outcome variable and must be uncorrelated with any other determinant of the dependent variable, which means that residual language training intensity at the job center level must not affect the employment probability of individuals other than through language course participation. A violation of this assumption occurs if individuals are aware of a job center's training intensity and intensify their job search to avoid being assigned language training. Individuals might also reduce their efforts to find a job if they prefer to participate in the language program and expect a high assignment probability. Moreover, they may move to other regions with lower/higher training intensity. As explained above, the residual training intensity should reflect the preferences/policy styles of job centers. The policy style of a job center is not communicated and hence unknown to individuals. Thus, it is very unlikely for unemployed individuals to change their behavior due to the actual (unobserved) training intensity at their job centers. For an individual, it is even more difficult to assess the level of the training intensity at a job center relative to others. In addition to applying these assumptions, I follow Caliendo et al. (2017) and apply a regression analysis where I adjust language training intensity $Z_{j}$ for regional economic and labor market conditions:

$$
Z_{j}=R_{j} \rho+\nu_{j}
$$

Residuals $\nu_{j}$ from the regression of instrument $Z_{j}$ on regional characteristics $R_{j}$ should then only reflect the job center-specific policy style and local preferences for the program. Conditional instrument $\widehat{\nu}_{i}$ is then regressed on observed individual characteristics $X_{i}$ :

$$
\widehat{\nu}_{j}=X_{i} \tau+\mu_{i}
$$

If these characteristics do not affect residual training intensity, the instrument creates exogenous variation in language training participation decisions that cannot be explained by observable differences between participants and nonparticipants.

The upper section of Table 3 shows the results of the regression of instrument $Z_{j}$ on regional characteristics $R_{j}$. With an adjusted $R^{2}$ of 0.453 , regional characteristics explain a majority of the variation in local language training intensity. The lower part of Table 3 presents the number of significant coefficients and the adjusted $R^{2}$ of the second regression where the first column also shows the $R^{2}$ and the number of significant 
Table 3 Effect of observed individual characteristics on the (conditional) instrument

Regression of instrument $Z_{j}$ on regional characteristics $R_{j}$

Unemployment rate of foreign-born

$0.001 * * *$

(0.000)

Unemployment rate of native-born

$-0.001 * * *$

(0.000)

Share of foreign-born among unemployed

$-0.043 * * *$

(0.002)

Share of foreign-born in labor force

$0.056 * * *$

(0.004)

Share of low-skilled among foreign-born

Share of women among foreign-born

Share of foreign-born among different age groups ${ }^{\mathrm{a}}$

****

Share of foreign-born from different regions of origin ${ }^{\mathrm{a}}$

****

Number of unemployed per vacancy

$-0.000 * * *$

Share of unemployed entering ALMP programs

Job center-specific treatment intensities for different ALMPs for immigrants

Placement budget

Activation/integration measures (provider)

Activation/integration measures (employer)

Training

Wage subsidies

Job creation scheme

Share of working population in different sectors ${ }^{\mathrm{a}}$

GDP per capita $\left(10,000^{-1}\right)$

Population density $\left(10,000^{-1}\right)$

Adj. $R^{2}$

Regression of (conditional) instrument $Z_{j} / v_{j}$ on observed individual characteristics $X_{i}$

$\begin{array}{lll} & Z_{j} & v_{j} \\ \text { Number of significant coefficients (5\% level) } & 50 \text { (out of 147) } & 13 \text { (out of 147) } \\ \text { Adj. } R^{2} & 0.045 & 0.002\end{array}$

Source: IEB V12.01.00, WGH V01.01.00-201604; Statistics of the German Federal Employment Agency; German Federal Statistical Office. Note: Estimation includes federal state dummies and time fixed-effects. Variables $X_{i}$ include socio-demographic characteristics, labor market history, and time fixed-effects. $* / * * / * * *$ indicate significant marginal effects at the $10 \% / 5 \% / 1 \%$ level. Standard errors are in parentheses and clustered at the job center level. ${ }^{a}$ Coefficients are jointly significantly different from zero. The categories for these variables can be found in Appendix Table 11 
coefficients of the regression of unconditional instrument $Z_{j}$ on $X_{i}$. With an $R^{2}$ of 0.045 , individual characteristics already only explain a small share of the variance of unconditional instrument $Z_{j}$. Nevertheless, the number of significant coefficients and $R^{2}$ decline when regional characteristics are considered. Only 13 of 147 coefficients are still significant, and they only explain $0.2 \%$ of the variance in conditional language training intensity. Residual language training intensity (and even unconditional language training intensity) is hardly correlated with the individual characteristics. Thus, after controlling for factors reflecting local labor market conditions, differences with respect to observed characteristics of jobseekers do not influence local policy style. Nevertheless, I also control for these individual characteristics in the instrumental variable analysis.

\section{Empirical results}

\subsection{Main results}

I estimate the effects of the language training program on employment probability for each month up to 24 months after the treatment starts. ${ }^{10}$ For the main specification, I concentrate on regular employment, i.e., full-time or part-time employment subject to social security contributions. In addition to socio-demographic control variables and variables for detailed labor market history up to 5 years before the (hypothetical) start of language training, I include variables for labor market status prior to the (hypothetical) start of language training, dummy variables for the duration of the current unemployment period and variables indicating the time elapsed since the first spell in the data. I also have variables for the last occupation and the skill level of the last job and dummies for individuals who did not work before. At the regional level, in addition to the variables included in Table 2, I control for the industry composition, the age composition of foreign-born individuals, and their composition with respect to the region of origin. Moreover, I include calendar month dummies.

I use the described IV approach and estimate a bivariate probit model with lagged monthly language training intensities as an instrument. I also estimate a probit model without taking the endogeneity of participation in the language course into account. Figure 1 shows the results for both models for each month after the (potential) start of language training. Detailed results for months $6,12,18$, and 24 can be found in Table 4. ${ }^{11}$

\footnotetext{
${ }^{10}$ As I only have information on the actual duration of the course and not on the planned duration, I do not differentiate between full-time (approx. 6 months) and part-time (approx. 12 months) language training courses in the analysis. If I were to split the sample by language program length, I would not be able to distinguish participants attending a part-time course and leaving after at most 6 months from those completing a full-time course. Dividing the sample and running estimations separately for courses with an actual duration of up to 6 months and of more than 6 months shows similar results. The lock-in effects are naturally somewhat more pronounced for part-time courses, but for the end of the observation period, they are somewhat higher.

${ }^{11}$ The full estimation results are available from the author upon request.

12 Bootstrapped standard errors for the bivariate probit model are only slightly different and lead to the same conclusions about the significance of the effects.
} 


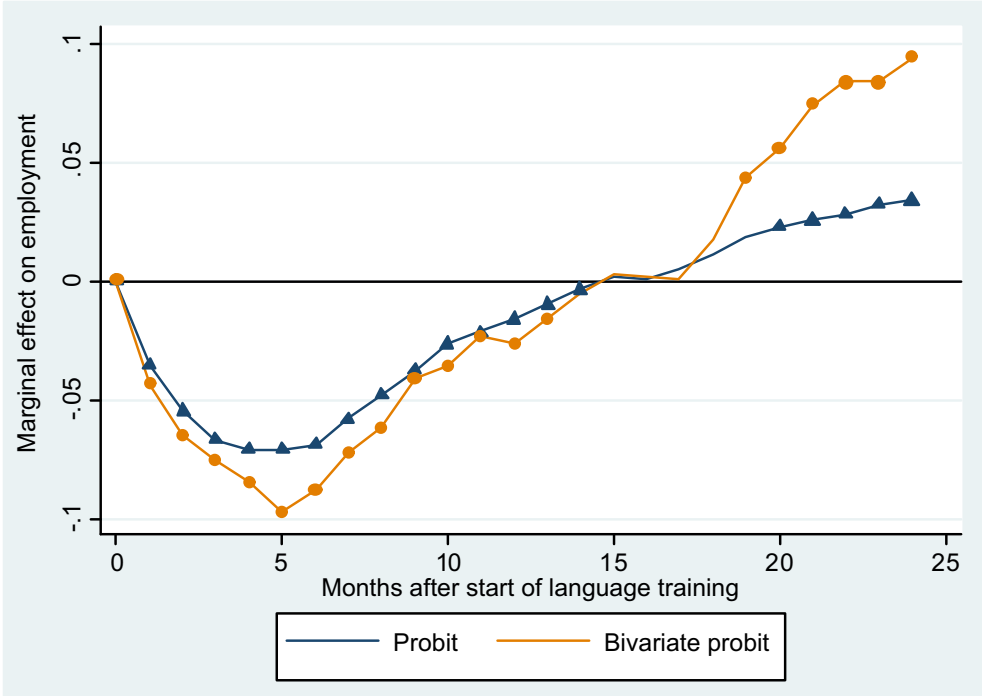

Fig. 1 Marginal effects of language training on regular employment. Source: IEB V12.01.00, WGH V01.01.00-201604; Statistics of the German Federal Employment Agency; German Federal Statistical Office. Note: Dots and triangles indicate significance at the $5 \%$ level. Standard errors clustered at the job center level

The results of both models show strong lock-in effects (see Fig. 1). Participation in language training significantly reduces employment probability for more than 1 year after its start. With a regular duration of 6 months of the course in full-time study, the negative effects reach their maximum of approximately -10 to -7 percentage points 5 months after the (hypothetical) start of the language course. Afterwards, the employment effects of language training increase and become positive after approximately 18 months in both models. The results of the bivariate probit model show that after 24 months, participation in language training increases the employment probability of immigrants by 9.4 percentage points (see Table 4). ${ }^{12}$ As the employment share of nonparticipants after 24 months is $24.5 \%$, this is a large effect of $38 \%$. As mentioned above, the program consists of different parts and, in addition to language training, includes firm visits and an internship. Unfortunately, with the data at hand, there is no possibility to disentangle the employment effects of the language training from the employment effects of the practical part. Although it is likely that the combination of both is beneficial for the employment prospects of the participants, it is not possible to identify the relative contributions of the different components of the program.

With regard to the relevance of the instrument, Table 4 shows that the lagged local training intensity has a very strong impact on the probability of participating in language training. In all estimations, it is highly significant. An increase in the lagged language training intensity by 1 percentage point increases the probability of participation by 2 percentage points. At least for the later months, a Wald test shows that endogeneity is present and that the IV approach is appropriate.

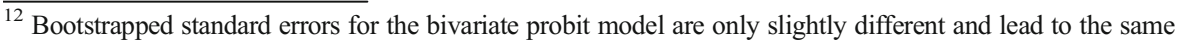
conclusions about the significance of the effects.
} 
Table 4 Marginal regular employment effects of language training and first-stage results of the bivariate probit model

\begin{tabular}{|c|c|c|c|c|}
\hline Month after language training start & 6 & 12 & 18 & 24 \\
\hline \multicolumn{5}{|l|}{ Bivariate probit } \\
\hline $\begin{array}{l}\text { Participation in language } \\
\text { training }\end{array}$ & $\begin{array}{l}-0.088 * * * \\
(0.011)\end{array}$ & $\begin{array}{l}-0.027 * * * \\
(0.015)\end{array}$ & $\begin{array}{l}0.017 \\
(0.018)\end{array}$ & $\begin{array}{l}0.094 * * * \\
(0.020)\end{array}$ \\
\hline \multicolumn{5}{|c|}{ First stage (dependent variable: participation in language training) } \\
\hline Language training intensity & $\begin{array}{l}2.081 * * * \\
(0.486)\end{array}$ & $\begin{array}{l}2.094 * * * \\
(0.486)\end{array}$ & $\begin{array}{l}2.095 * * * \\
(0.488)\end{array}$ & $\begin{array}{l}2.105 * * * \\
(0.492)\end{array}$ \\
\hline Chi-square of test for exogeneity & $3.571 *$ & 0.582 & 0.140 & $11.665^{* * * *}$ \\
\hline \multicolumn{5}{|l|}{ Probit } \\
\hline $\begin{array}{l}\text { Participation in language } \\
\text { training }\end{array}$ & $\begin{array}{l}-0.069 * * * \\
(0.004)\end{array}$ & $\begin{array}{l}-0.016^{* * * *} \\
(0.006)\end{array}$ & $\begin{array}{l}0.011 * \\
(0.006)\end{array}$ & $\begin{array}{l}0.034 * * * \\
(0.007)\end{array}$ \\
\hline $\begin{array}{l}\text { Mean employment rate } \\
\text { of non-participants }\end{array}$ & 0.136 & 0.185 & 0.218 & 0.245 \\
\hline$N$ & 35,431 & & & \\
\hline
\end{tabular}

Source: IEB V12.01.00, WGH V01.01.00-201604; Statistics of the German Federal Employment Agency; German Federal Statistical Office

Note: All estimations include socio-demographic characteristics, labor market history, regional variables, and time fixed-effects. $* * * * * * *$ indicate significant marginal effects at the $10 \% / 5 \% / 1 \%$ level. Standard errors in parentheses, clustered at the job center level

A comparison of the effects of the IV and probit models shows that taking endogeneity into account has a strong impact on the results. For the last 6 months of the observation period (1.5 to 2 years after the start of the language course), the positive effects are much greater in the bivariate probit model than in the probit model. The employment effect of language training 24 months after its start is 3.4 percentage points and thus lower in the probit model. Thus, not controlling for endogenous language training participation leads to underestimating employment effects.

The results for a period of 24 months given in Fig. 1 indicate that negative employment effects at the beginning of the observation period exceed positive effects at the end. To see whether the positive trend of employment effects continues and to assess if aggregated employment effects can be expected to turn positive, I conducted a further analysis where I estimate the bivariate probit model for participants who started a language training course between February and June 2014 and non-participants with a hypothetical start date within this period $(N=11,811)$. For this group, I can extend the observation period by 6 months. The results can be found in Appendix Figure 3. For the first 2 years, the pattern of marginal effects appears similar to that found for all participants for February to December 2014 with the exception of a dip in employment effects after 21 months. After 26 months, there is a strong increase in employment effects, and positive effects after a certain point in time offset and even outweigh the negative effects at the beginning of the observation period. 


\subsection{Further labor market outcomes}

So far, this analysis has concentrated on regular employment, i.e., employment subject to social insurance contributions. To draw more detailed insights into types of jobs and their quality, I show in this section how participation in the language course affects further labor market outcomes. First, Table 5 presents the effects on different types of employment 24 months after (hypothetical) treatment start. In addition to regular employment in the second column, I consider total employment, including regular and marginal employment, regular full-time employment and regular employment for at least 6 months with the same employer. I also only consider employment with a daily wage above the risk of poverty threshold (which was $1033 €$ per month in Germany in 2014). Finally, I consider only skilled employment, coding unskilled jobs as zero.

When comparing the results for total and regular employment, marginal employment only seems to play a minor role in the labor market prospects of the participants. Additionally, the results for regular full-time and permanent regular employment for at least 6 months show that the participants are more likely to find stable and substantial employment. The results for skilled employment show that the employment effects are not driven by people finding unskilled jobs. Given that only $15.5 \%$ of the nonparticipants have a skilled job after 24 months, an effect of language training of 7.1 percentage points is substantial.

In addition, Table 6 shows the effects on (cumulated) earnings and cumulated employment after 24 months as well as the effects on further labor market states: apprenticeship training, unemployment, and non-registration in the data. As (cumulated) earnings and cumulated employment are continuous variables, I use a linear IV model instead of the bivariate probit model for estimating the effects of language training on these outcomes, and thus I do not estimate an ATE here, but a local average treatment effect for compliers.

The results for the other three labor market statuses show that participating in language training does not significantly reduce the probability of being unemployed but strongly reduces the probability of non-registration. Non-registration may mostly reflect dropouts of the labor market but also, for example, remigration. The observed absence of an effect of language training on unemployment but positive effects on employment may be explained by the fact that language training keeps the participants in the (German) labor market. Finally, although there is anecdotal evidence that participants are likely to start apprenticeship training (which typically takes 2 to 3 years) after the language course, this is not confirmed by the analysis. The effect shown in the IV model is positive but insignificant.

For daily income from employment (where missing income due to nonemployment is coded as zero), the effect of language training of $8.66 €$ is very strong (the mean daily income of non-participants is $12.76 €$ ) but insignificant. The effects on cumulated outcomes are negative in the OLS models but positive for the IV models. However, the effect on cumulated income is insignificant and the effect on cumulated days in employment is significant only on the $10 \%$ level. As shown in Section 5.1, the program has a strong lock-in effect and it takes more than 2 years after the program starts to compensate for negative employment and 


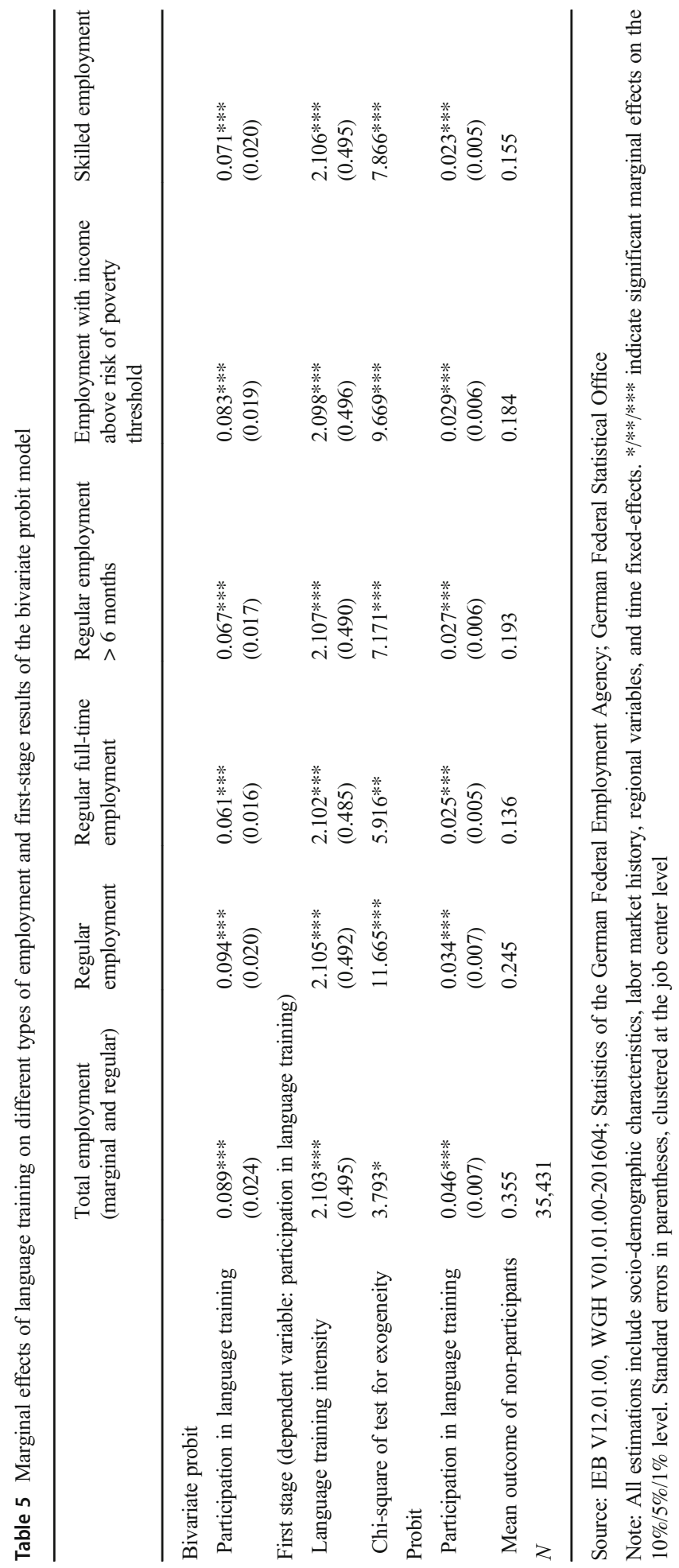




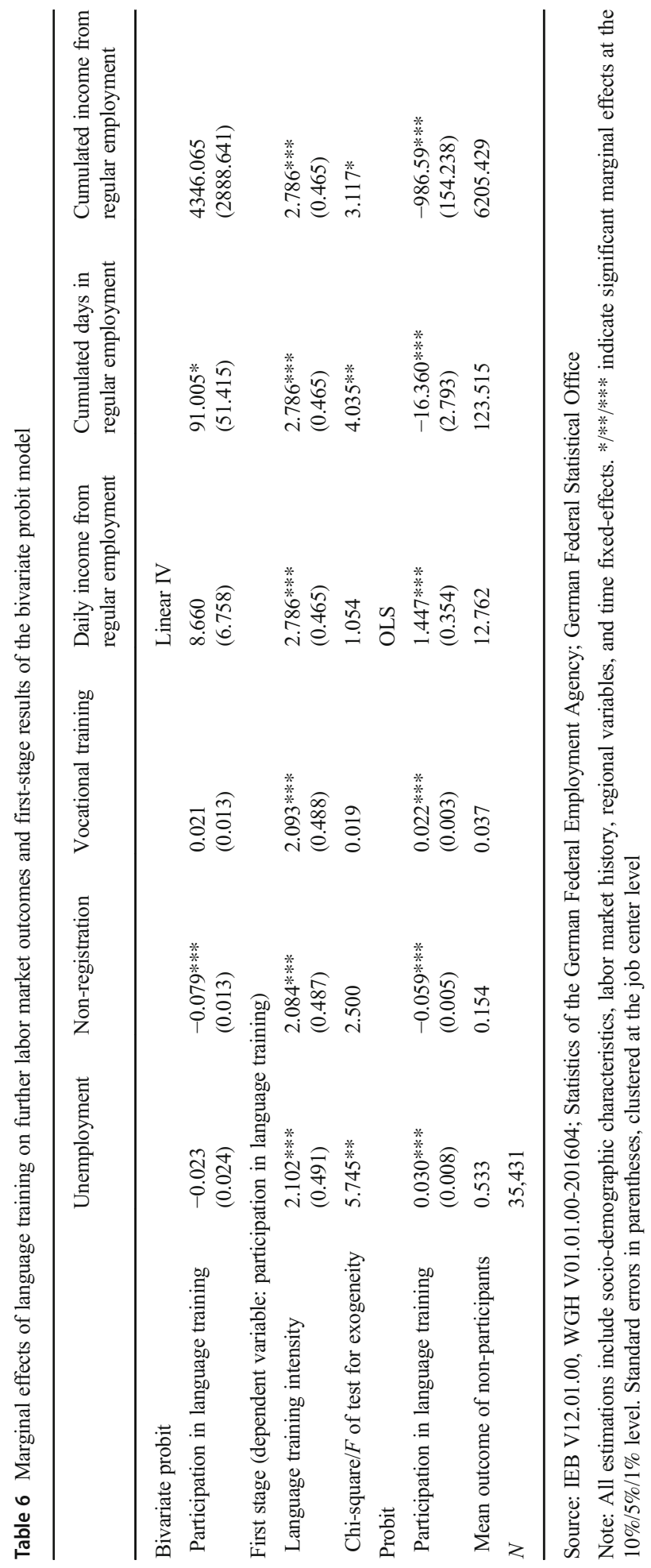


income effects due to program participation in the first months of the observation period. $^{13}$

In sum, language training improves the employment prospects of participants not only quantitatively but also qualitatively. The overall effect is not driven by marginal employment, and participation increases the chances of finding a skilled job by $45 \%$. Although language training does not significantly reduce unemployment, it reduces the probability of leaving the (German) labor market. Considering cumulated outcomes, 2 years after the start of the course, the lock-in effects of language training are compensated but not outweighed by positive treatment effects.

\subsection{Heterogeneous effects}

In this section, I analyze whether the effectiveness of language training differs for different subgroups. I concentrate on regular employment subject to social security contributions. First, Table 7 shows that the absolute employment effect for men 24 months after the (hypothetical) start of the program is 14.8 percentage points, and thus twice as high as that for women. However, as the employment rate for women after 24 months is much lower than the employment rate for men (18.7 and $31.7 \%$ for female and male non-participants, respectively), differences in the relative effects are less pronounced. The majority of individuals in my sample have no vocational degree. As language skills may be more important in qualified jobs, there could also be differences by vocational qualification. The results listed in Table 7 show that with 8.9 percentage points, the employment effect of language training for individuals without vocational or university degree is smaller after 2 years than the effect for individuals with a vocational degree (18.0 percentage points). The effect is insignificant and less pronounced for those with a university degree. Non-participants with the highest levels of education may also improve their language skills through other means or may even work in positions where English is the most important language in a company.

Another interesting aspect concerns the timing of language training. On average, participants start the language course 76 months after they enter the German labor market as measured by the duration since the first observed spell in the IEB data. More than one-quarter of the participants, however, entered the program within 2 years after their first spell in the data (see Appendix Figure 2). Table 8 shows the employment effects of language training 24 months, 25 to 60 months, and over 60 months after entering the German labor market. The results show a negative correlation between the effectiveness of language training and the duration individuals are observed in the German labor market. ${ }^{14}$ Twenty-four months after its start, language training increases the employment rate of individuals by 11.9 percentage points when starting within 2 years. For individuals observed in the data for more than 60 months, the effects are very

\footnotetext{
${ }^{13}$ Restricting the sample to workers who (hypothetically) started a language training course between February and June 2014 to extend the observation period by 6 months as in Section 5.1 strongly reduces the sample size. As the estimates from the linear IV model are much less precise than those from the binary probit model, I do not obtain significant effects for cumulated outcomes after 36 months for that small sample.

${ }^{14}$ In line with this result, the employment effect of language training is smaller for long-term unemployed workers (5.0 percentage points).
} 
Table 7 Marginal employment effects of language training and first-stage results of the bivariate probit model 24 months after start of language training by gender and vocational degree

\begin{tabular}{|c|c|c|c|c|c|}
\hline & \multicolumn{2}{|l|}{ Gender } & \multicolumn{3}{|c|}{ Vocational degree } \\
\hline & Women & Men & No degree & $\begin{array}{l}\text { Vocational } \\
\text { degree }\end{array}$ & $\begin{array}{l}\text { University } \\
\text { degree }\end{array}$ \\
\hline \multicolumn{6}{|l|}{ Bivariate probit } \\
\hline Participation in language training & $\begin{array}{l}0.072 * * * \\
(0.022)\end{array}$ & $\begin{array}{l}0.148 * * * \\
(0.034)\end{array}$ & $\begin{array}{l}0.084 * * * \\
(0.023)\end{array}$ & $\begin{array}{l}0.180 * * * \\
(0.052)\end{array}$ & $\begin{array}{l}0.074 \\
(0.078)\end{array}$ \\
\hline \multicolumn{6}{|c|}{ First stage (dependent variable: participation in language training) } \\
\hline Language training intensity & $\begin{array}{l}1.988^{* * * *} \\
(0.661)\end{array}$ & $\begin{array}{l}2.244 * * * \\
(0.446)\end{array}$ & $\begin{array}{l}2.208^{* * * *} \\
(0.506)\end{array}$ & $\begin{array}{l}1.937 * * * \\
(0.619)\end{array}$ & $\begin{array}{l}1.463 \\
(0.924)\end{array}$ \\
\hline Chi-square of test for exogeneity & $3.993 * * *$ & $12.058 * * *$ & $6.241 * *$ & $5.477 * *$ & $9.483 * * *$ \\
\hline \multicolumn{6}{|l|}{ Probit } \\
\hline Participation in language training & $\begin{array}{l}0.032 * * * \\
(0.008)\end{array}$ & $\begin{array}{l}0.038 * * * \\
(0.011)\end{array}$ & $\begin{array}{l}0.030^{* * * *} \\
(0.008)\end{array}$ & $\begin{array}{l}0.065 * * * \\
(0.017)\end{array}$ & $\begin{array}{l}0.004 \\
(0.020)\end{array}$ \\
\hline Mean employment rate of non-participants & 0.187 & 0.317 & 0.221 & 0.316 & 0.302 \\
\hline$N$ & 20,179 & 15,252 & 24,897 & 6516 & 4018 \\
\hline
\end{tabular}

Source: IEB V12.01.00, WGH V01.01.00-201604; Statistics of the German Federal Employment Agency; German Federal Statistical Office

Note: All estimations include socio-demographic characteristics, labor market history, regional variables, and time fixed-effects. $* * * * * * *$ indicate significant marginal effects at the $10 \% / 5 \% / 1 \%$ level. Standard errors in parentheses, clustered at the job center level

small and insignificant in the case of bivariate probit estimates. These results indicate that an early provision of language programs benefits the labor market integration of migrants.

\subsection{Robustness of the results}

\subsubsection{Robustness tests regarding eligibility for language training}

Although all non-participants in the sample have a migration background and are unemployed, which are two of the conditions for participation, I do not know if they really meet the remaining eligibility criteria for the language training program. In particular, I do not know whether they have German skills of a very basic level, which is another prerequisite for participation. To avoid comparing participants to non-eligible participants, I try to exclude individuals without German skills and focus on a subsample of individuals with prior integration course participation to identify appropriate non-participants. As more than $90 \%$ of all integration course participants who finish the course pass the associated exams with a language level of A2 or B1 (BAMF 2017), they should have obtained language skills that are sufficient for participating in the language training program. As the data do not provide information on whether integration course participants passed the final exams, I only include individuals who attended an 
Table 8 Marginal employment effects of language training and first-stage results of the bivariate probit model 24 months after start of language training by duration since first observation

\begin{tabular}{|c|c|c|c|}
\hline Duration since first observation in data & Up to 24 months & 25-60 months & More than 60 months \\
\hline \multicolumn{4}{|l|}{ Bivariate probit } \\
\hline Participation in language training & $\begin{array}{l}0.119 * * * \\
(0.033)\end{array}$ & $\begin{array}{l}0.069^{* *} \\
(0.033)\end{array}$ & $\begin{array}{l}0.009 \\
(0.029)\end{array}$ \\
\hline \multicolumn{4}{|c|}{ First stage (dependent variable: participation in language training) } \\
\hline Language training intensity & $\begin{array}{l}1.257 * * * \\
(0.419)\end{array}$ & $\begin{array}{l}1.436^{* *} \\
(0.562)\end{array}$ & $\begin{array}{l}1.957 * * * \\
(0.694)\end{array}$ \\
\hline Chi-square of test for exogeneity & $4.008^{* *}$ & 0.272 & 0.140 \\
\hline \multicolumn{4}{|l|}{ Probit } \\
\hline Participation in language training & $\begin{array}{l}0.063 * * * \\
(0.015)\end{array}$ & $\begin{array}{l}0.053 * * * \\
(0.013)\end{array}$ & $\begin{array}{l}0.018^{* *} \\
(0.009)\end{array}$ \\
\hline Mean employment rate of non-participants & 0.273 & 0.258 & 0.223 \\
\hline$N$ & 9561 & 9208 & 16,662 \\
\hline
\end{tabular}

Source: IEB V12.01.00, WGH V01.01.00-201604; Statistics of the German Federal Employment Agency; German Federal Statistical Office

Note: All estimations include socio-demographic characteristics, labor market history, regional variables, and time fixed-effects. $* * * * * * *$ indicate significant marginal effects at the $10 \% / 5 \% / 1 \%$ level. Standard errors in parentheses, clustered at the job center level

integration course in the past for at least 2 months. I also include a variable for days spent in integration courses in the past in my estimations and control for time elapsed since the last day in such a course.

As a second condition for participation in the language program, language skills must not be strong enough to successfully enter the German labor market. This condition is more likely to hold for individuals completing an integration course only recently and without much time to advance their German skills afterwards. As the sample size becomes smaller the shorter the chosen time window for prior integration course participation is, I present results for different time windows: for individuals who attended an integration course at some time in the past and over the last 1 or 5 years. For the subsample of individuals who attended an integration course over the last year, it is reasonable to assume that participants and non-participants did not have many possibilities to significantly advance their German skills in some months.

Table 9 shows the marginal effects of language training on regular employment 24 months after its start for former integration course participants. The results for the subsamples go in the same direction as the results for the full sample where the results indicate that language training increases the employment probability by 9.4 percentage points. For the first two subsamples (integration course taken in the past and over the past 5 years), with 8.7 and 9.0 percentage points, respectively, employment effects are only slightly smaller but only significant at the $10 \%$ level. For individuals attending an integration course within the last year before (hypothetical) participation in language training, the effect of $16.7 \%$ is even higher than the baseline estimates and highly significant. Overall, the results are robust to restricting the sample to individuals with basic German skills. 
Table 9 Marginal employment effects of language training and first-stage results of the bivariate probit model 24 months after start of language training - former integration course participants

\begin{tabular}{llll}
\hline Integration course participation & Some time in the past & Last 5 years & Last year \\
\hline Bivariate probit & & & \\
Participation in language training & $0.087^{*}$ & $0.090^{*}$ & $0.167^{* * *}$ \\
& $(0.046)$ & $(0.047)$ & $(0.049)$ \\
First stage (dependent variable: participation in language training) & & $3.150^{* * *}$ & $2.532^{* * *}$ \\
Language training intensity & $2.961^{* * *}$ & $(1.914)$ & $(1.112)$ \\
& $(0.894)$ & 1.060 & $4.305^{* *}$ \\
Chi-square of test for exogeneity & 1.170 & & $0.064^{* * *}$ \\
Probit & & $0.044 * * *$ & $(0.014)$ \\
Participation in language training & $0.039^{* * *}$ & $(0.010)$ & 0.285 \\
Mean employment rate of non-participants & 0.238 & 0.244 & 6040 \\
$N$
\end{tabular}

Source: IEB V12.01.00, WGH V01.01.00-201604; Statistics of the German Federal Employment Agency; German Federal Statistical Office

Note: All estimations include socio-demographic characteristics, labor market history, regional variables, and time fixed-effects. $* / * * / * * *$ indicate significant marginal effects at the $10 \% / 5 \% / 1 \%$ level. Standard errors in parentheses, clustered at the job center level

\subsubsection{Further robustness tests}

The baseline sample used for this analysis includes non-participants with a similar distribution of the variable measuring the duration from the first observation in the IEB data as the participants. To determine whether the results are robust to this sample selection procedure, I also run the estimations on the total sample (see Table 10). On the other extreme, I apply one-to-one nearest neighbor matching on all individual characteristics to generate a sample with even more similar treated and non-treated individuals. The effects for the full sample are lower than those of the baseline sample but are positive and highly significant whereas effects for the matched sample are even stronger than they are for the baseline sample.

Moreover, the last column in Table 10 shows the results from a linear IV model. The linear IV identifies a local average treatment effect (LATE) of 21.7 percentage points. This effect can differ from the ATE obtained from the bivariate probit model. This is this case, which indicates that there is effect heterogeneity and the bivariate probit model is appropriate.

Finally, Table 1 shows that the treatment and control groups differ with respect to certain characteristics, e.g., the country of origin and pretreatment status. Appendix Table 12 shows that the results are robust to excluding certain groups of immigrants. 
Table 10 Marginal employment effects of language training and first-stage results of the bivariate probit model 24 months after start of language training from robustness tests

\begin{tabular}{|c|c|c|c|}
\hline Sample & Full sample & Matched sample $(1: 1 \mathrm{NN})$ & Baseline sample \\
\hline Bivariate probit & & & Linear IV \\
\hline Participation in language training & $\begin{array}{l}0.057 * * * \\
(0.015)\end{array}$ & $\begin{array}{l}0.154 * * * \\
(0.049)\end{array}$ & $\begin{array}{l}0.217 * \\
(0.122)\end{array}$ \\
\hline \multicolumn{4}{|c|}{ First stage (dependent variable: participation in language training) } \\
\hline Language training intensity & $\begin{array}{l}0.756 * * * \\
(0.126)\end{array}$ & $\begin{array}{l}2.907 * * * \\
(0.562)\end{array}$ & $\begin{array}{l}2.786 * * * \\
(0.465)\end{array}$ \\
\hline Chi-square of test for exogeneity & $4.003^{* *}$ & $5.779^{* *}$ & \\
\hline Probit & & & OLS \\
\hline Participation in language training & $\begin{array}{l}0.031 * * * \\
(0.006)\end{array}$ & $\begin{array}{l}0.034 * * * \\
(0.006)\end{array}$ & $\begin{array}{l}0.032 * * * \\
(0.007)\end{array}$ \\
\hline Mean employment rate of non-participants & 0.222 & 0.240 & 0.245 \\
\hline$N$ & 130,114 & 17,930 & 35,365 \\
\hline
\end{tabular}

Source: IEB V12.01.00, WGH V01.01.00-201604; Statistics of the German Federal Employment Agency; German Federal Statistical Office

Note: All estimations include socio-demographic characteristics, labor market history, regional variables, and time fixed-effects. $* / * * / * * *$ indicate significant marginal effects at the $10 \% / 5 \% / 1 \%$ level. Standard errors in parentheses, clustered at the job center level

\section{Conclusion}

Language barriers facing immigrants greatly hamper labor market integration. Formal language training could help accelerate the integration process. In this paper, I analyze employment effects of a language training program providing German language training with a focus on employment-related topics on immigrants in Germany.

The results of bivariate probit estimations show that after a lock-in period, participation in language training increases participants' employment probability. Two years after the start of the program, they show a higher employment probability of more than nine percentage points. The results are not driven by marginal or low-skilled jobs, as participants more likely to find stable and skilled work. Moreover, I find that the language program is more effective when it is taken soon after entering the German labor market.

The clearly positive effects found here stand in contrast to some results of the (few) previous studies conducted on the effects of language training. This may be attributable to the program's strong orientation towards specific (linguistic) requirements of the labor market. Moreover, particular features of the program such as application training and work placements go beyond the content of the commonly very general language courses mainly offered to immigrants. Although it is probably the combination of language training and the practical part that makes the program successful, this study is not able to identify the relative contributions of the different components. 
Previous studies on ALMP measures for immigrants have shown that the most effective measures are those that enable contact with the labor market (Rinne 2013). As the language program examined in this study includes firm visits and an internship, these additional features of the program may be important for its effectiveness. Overall, providing language training with a strong focus on the labor market seems to be a promising strategy and should be for other immigration countries as well.

Due to observation numbers that are too low for some groups, I do not distinguish between participants of different regions of origins. It would be even more interesting to differentiate people according to the linguistic distance of their first language from the German language. Although people from countries with a more similar language can profit more from the examined course since they can more easily learn German, the effects may also be stronger for individuals with a very different first language. As such individuals will face more difficulties in learning the language in everyday life, they may particularly benefit from formal language training.

\section{Appendix}

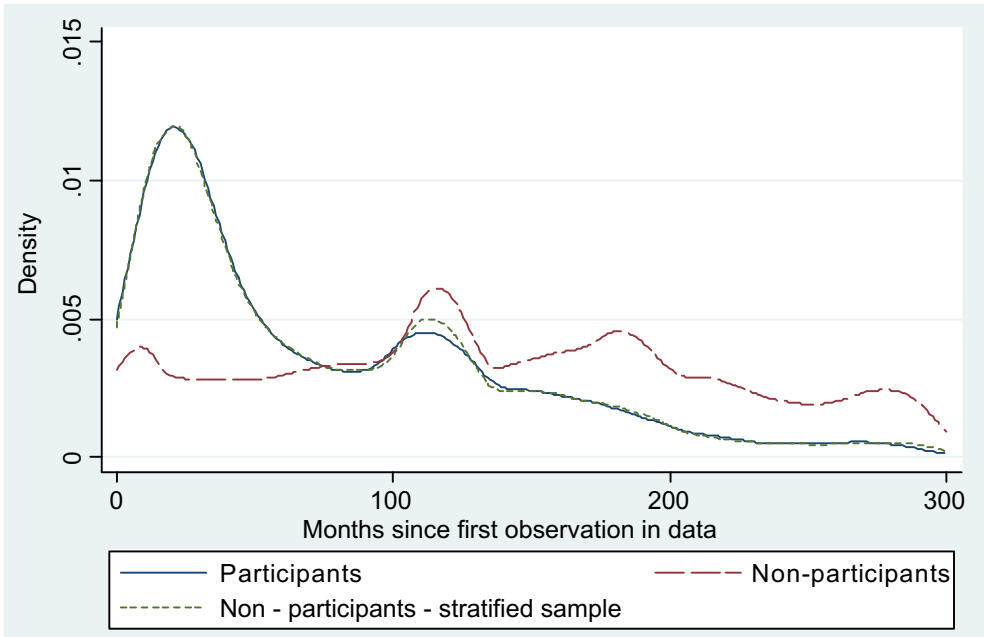

Fig. 2. Distribution of duration since first observation in the IEB data. Source: IEB V12.01.00, WGH V01.01.00-201604 


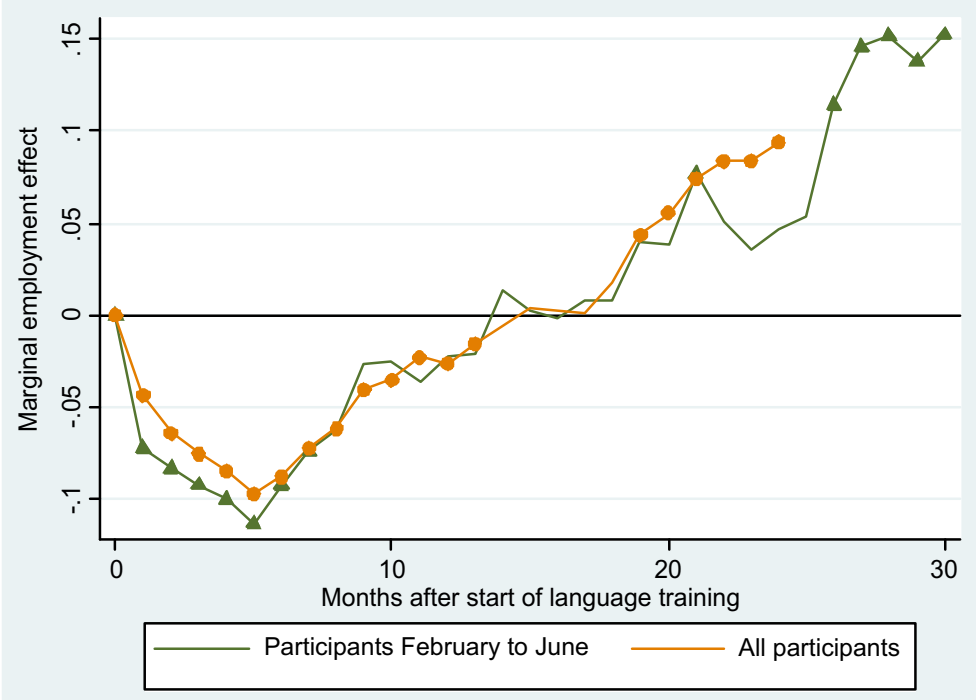

Fig. 3. Marginal employment effects of language training on employment for participants starting between February and June 2014 and all participants in the sample - bivariate probit models. Source: IEB V12.01.00, WGH V01.01.00-201604; Statistics of the German Federal Employment Agency; German Federal Statistical Office. Note: Dots indicate significance at the 5\% level. Standard errors clustered at the job center level

Table 11 Mean values of control variables

\begin{tabular}{|c|c|c|c|c|}
\hline & Participants & $\begin{array}{l}\text { Non- } \\
\text { participants }\end{array}$ & $\begin{array}{l}\text { High treatment } \\
\text { intensity } \\
\text { ( } \geq \text { median) }\end{array}$ & $\begin{array}{l}\text { Low treatment } \\
\text { intensity } \\
(<\text { median })\end{array}$ \\
\hline \multicolumn{5}{|l|}{ Individual-level variables } \\
\hline Male & 0.376 & $0.449 * * *$ & 0.460 & 0.462 \\
\hline Age & 36.101 & $33.318 * * *$ & 34.110 & $33.654 *$ \\
\hline Age $\leq 30$ at first spell in IEB data & 0.347 & $0.523 * * *$ & 0.467 & $0.496 * * *$ \\
\hline Children & 0.559 & $0.428 * * *$ & 0.468 & $0.441 * * *$ \\
\hline \multicolumn{5}{|l|}{ Marital status } \\
\hline Single & 0.262 & $0.324 * * *$ & 0.305 & 0.315 \\
\hline Married, separated & 0.011 & $0.003 * * *$ & 0.007 & $0.003 * *$ \\
\hline Married & 0.519 & $0.440 * * *$ & 0.460 & 0.457 \\
\hline Divorced & 0.012 & $0.005^{* * *}$ & 0.009 & 0.007 \\
\hline Widowed & 0.002 & $0.001 * * *$ & 0.002 & 0.001 \\
\hline Unknown & 0.194 & $0.227 * * *$ & 0.217 & 0.218 \\
\hline \multicolumn{5}{|l|}{ Highest educational degree } \\
\hline No vocational degree & 0.507 & $0.656 * * *$ & 0.583 & $0.642 * * *$ \\
\hline German or unknown vocational degree & 0.046 & $0.087 * * *$ & 0.083 & 0.088 \\
\hline $\begin{array}{l}\text { Higher secondary schooling degree and } \\
\text { no vocational degree }\end{array}$ & 0.118 & $0.073 * * *$ & 0.076 & 0.073 \\
\hline
\end{tabular}


Table 11 (continued)

\begin{tabular}{|c|c|c|c|c|}
\hline & Participants & $\begin{array}{l}\text { Non- } \\
\text { participants }\end{array}$ & $\begin{array}{l}\text { High treatment } \\
\text { intensity } \\
\text { ( } \geq \text { median) }\end{array}$ & $\begin{array}{l}\text { Low treatment } \\
\text { intensity } \\
(<\text { median })\end{array}$ \\
\hline $\begin{array}{l}\text { Higher secondary schooling degree and } \\
\text { German vocational degree }\end{array}$ & 0.011 & $0.018^{* * *}$ & 0.015 & 0.016 \\
\hline German or unknown university degree & 0.030 & $0.025 * * *$ & 0.027 & 0.024 \\
\hline Vocational degree abroad & 0.132 & $0.077 * * *$ & 0.116 & $0.090 * * *$ \\
\hline University degree abroad & 0.156 & $0.064 * * *$ & 0.101 & $0.067 * * *$ \\
\hline \multicolumn{5}{|l|}{ Schooling degree } \\
\hline No secondary degree & 0.223 & $0.257 * * *$ & 0.198 & $0.245^{* * *}$ \\
\hline Lower secondary degree & 0.238 & $0.337 * * *$ & 0.334 & $0.359 * *$ \\
\hline Lower or middle secondary degree & 0.011 & $0.032^{* * *}$ & 0.021 & 0.025 \\
\hline Middle secondary degree & 0.160 & 0.161 & 0.187 & $0.159 * * *$ \\
\hline $\begin{array}{l}\text { Higher secondary degree } \\
\text { (Fachhochschulreife) }\end{array}$ & 0.059 & $0.044 * * *$ & 0.049 & $0.040 * *$ \\
\hline $\begin{array}{l}\text { Higher secondary degree } \\
\text { (Fachhochschulreife or Abitur) }\end{array}$ & 0.031 & 0.029 & 0.034 & 0.030 \\
\hline Higher secondary degree (Abitur) & 0.279 & $0.141^{* * *}$ & 0.176 & $0.142 * * *$ \\
\hline \multicolumn{5}{|l|}{ Region of origin } \\
\hline EU countries & 0.295 & $0.329 * * *$ & 0.332 & 0.335 \\
\hline Turkey & 0.108 & $0.204^{* * * *}$ & 0.137 & $0.173 * * *$ \\
\hline Russia & 0.065 & $0.036^{* * *}$ & 0.062 & $0.045^{* * *}$ \\
\hline Other European countries & 0.071 & $0.109 * * *$ & 0.099 & 0.106 \\
\hline North Africa & 0.035 & 0.035 & 0.030 & 0.028 \\
\hline Other African countries & 0.069 & $0.045^{* * *}$ & 0.038 & 0.043 \\
\hline Near/Middle East & 0.246 & $0.177 * * *$ & 0.203 & 0.194 \\
\hline Other Asian countries & 0.076 & $0.046^{* * *}$ & 0.074 & $0.053 * * *$ \\
\hline America, Australia & 0.036 & $0.019 * * *$ & 0.025 & 0.023 \\
\hline \multicolumn{5}{|c|}{ Labor market history 1 year prior to (hypothetical) training start } \\
\hline Days in employment & 25.421 & $33.825 * * *$ & 35.910 & $41.093 * * *$ \\
\hline Days in job search & 294.426 & $246.220 * * *$ & 243.528 & 241.409 \\
\hline Number of job search episodes & 1.085 & $0.869 * * *$ & 0.913 & 0.917 \\
\hline Days in ALMP program & 16.732 & $21.614 * * *$ & 18.988 & 20.843 \\
\hline Number of episodes in ALMP program & 0.224 & $0.199 * * *$ & 0.200 & 0.209 \\
\hline Days with unemployment benefit receipt & 18.444 & $13.908 * * *$ & 14.963 & $18.119 * * *$ \\
\hline $\begin{array}{l}\text { Days with unemployment benefit II } \\
\text { receipt }\end{array}$ & 298.939 & $252.726^{* * * *}$ & 246.014 & $237.812 * *$ \\
\hline $\begin{array}{l}\text { Days with sickness absence during } \\
\text { unemployment }\end{array}$ & 2.080 & 2.251 & 2.347 & 2.053 \\
\hline $\begin{array}{l}\text { Number of episodes with unemployment } \\
\text { benefit receipt }\end{array}$ & 0.136 & 0.134 & 0.147 & $0.173 * * *$ \\
\hline $\begin{array}{l}\text { Number of episodes with unemployment } \\
\text { benefit II receipt }\end{array}$ & 1.028 & $0.992^{* * *}$ & 1.007 & 0.995 \\
\hline
\end{tabular}


Table 11 (continued)

\begin{tabular}{|c|c|c|c|c|}
\hline & Participants & $\begin{array}{l}\text { Non- } \\
\text { participants }\end{array}$ & $\begin{array}{l}\text { High treatment } \\
\text { intensity } \\
\text { ( } \geq \text { median) }\end{array}$ & $\begin{array}{l}\text { Low treatment } \\
\text { intensity } \\
(<\text { median })\end{array}$ \\
\hline $\begin{array}{l}\text { Number of episodes with sickness } \\
\text { absence during unemployment }\end{array}$ & 0.155 & 0.162 & 0.162 & 0.147 \\
\hline Mean wage & 6.441 & $8.604 * * *$ & 9.068 & $10.610 * * *$ \\
\hline Cumulated wage & 984.575 & $1438.650 * * *$ & 1498.759 & $1809.635 * * *$ \\
\hline Days in education & 5.695 & 43.998 & 34.099 & 35.177 \\
\hline Days in self-employment & 4.009 & $6.260 * * *$ & 5.416 & 5.221 \\
\hline Days in military/civilian service & 0.010 & $0.100^{*}$ & 0.143 & 0.044 \\
\hline $\begin{array}{l}\text { Days on parental leave, } \\
\text { housewife/househusband }\end{array}$ & 16.218 & $34.735^{* * *}$ & 31.446 & $27.126^{* *}$ \\
\hline Days in other measures & 6.481 & $3.478 * * *$ & 4.251 & $2.864 * * *$ \\
\hline Days with non-professional activities & 0.510 & $1.115^{* * * *}$ & 1.471 & 1.149 \\
\hline Days with other status & 48.325 & $90.801 * * *$ & 83.987 & $76.925 * * *$ \\
\hline Number of episodes in education & 0.034 & $0.188 * * *$ & 0.148 & 0.154 \\
\hline Number of episodes of self-employment & 0.023 & $0.031 * * *$ & 0.029 & 0.025 \\
\hline $\begin{array}{l}\text { Number of episodes on parental leave, } \\
\text { housewife/househusband }\end{array}$ & 0.077 & $0.137 * * *$ & 0.133 & $0.113 * * *$ \\
\hline Number of episodes in other measures & 0.066 & $0.030^{* * * *}$ & 0.038 & $0.026^{* * * *}$ \\
\hline Days in employment outside Germany & 2.406 & 2.913 & 3.953 & 3.702 \\
\hline \multicolumn{5}{|c|}{ Labor market history 5 years prior to (hypothetical) training start } \\
\hline Days in employment & 161.711 & $169.501 *$ & 167.646 & $195.395 * * *$ \\
\hline Days in job search & 932.607 & $826.067 * * *$ & 756.304 & 762.994 \\
\hline Number of job search episodes & 1.571 & $1.204 * * *$ & 1.257 & $1.325^{* *}$ \\
\hline Days in ALMP program & 64.265 & $85.300 * * *$ & 77.962 & 81.172 \\
\hline Number of episodes in ALMP program & 0.563 & $0.540^{*}$ & 0.551 & 0.537 \\
\hline Days with unemployment benefit receipt & 40.176 & $37.728 *$ & 36.792 & $44.604 * * *$ \\
\hline $\begin{array}{l}\text { Days with unemployment benefit II } \\
\text { receipt }\end{array}$ & 940.603 & $842.649 * * *$ & 757.181 & 754.865 \\
\hline $\begin{array}{l}\text { Days with sickness absence during } \\
\text { unemployment }\end{array}$ & 6.211 & $7.055 * *$ & 6.465 & 6.456 \\
\hline $\begin{array}{l}\text { Number of episodes with unemployment } \\
\text { benefit receipt }\end{array}$ & 0.239 & $0.275^{* * *}$ & 0.287 & $0.335 * * *$ \\
\hline $\begin{array}{l}\text { Number of episodes with unemployment } \\
\text { benefit II receipt }\end{array}$ & 1.366 & $1.475^{* * *}$ & 1.430 & $1.488 * *$ \\
\hline $\begin{array}{l}\text { Number of episodes with sickness } \\
\text { absence during unemployment }\end{array}$ & 0.408 & $0.479 * * *$ & 0.426 & 0.420 \\
\hline Mean wage & 1.621 & 1.592 & 1.310 & $1.635 * *$ \\
\hline Cumulated wage & 1373.180 & 1237.835 & 1046.881 & $1347.951 * *$ \\
\hline Days in education & 120.165 & $302.992 * * *$ & 251.717 & 260.945 \\
\hline Days in self-employment & 56.331 & 54.898 & 54.703 & $46.613 *$ \\
\hline Days in military/civilian service & 1.760 & 1.248 & 2.399 & $0.919 * * *$ \\
\hline
\end{tabular}


Table 11 (continued)

\begin{tabular}{|c|c|c|c|c|}
\hline & Participants & $\begin{array}{l}\text { Non- } \\
\text { participants }\end{array}$ & $\begin{array}{l}\text { High treatment } \\
\text { intensity } \\
\text { ( } \geq \text { median) }\end{array}$ & $\begin{array}{l}\text { Low treatment } \\
\text { intensity } \\
(<\text { median })\end{array}$ \\
\hline $\begin{array}{l}\text { Days on parental leave, } \\
\text { housewife/househusband }\end{array}$ & 177.580 & 175.473 & 178.022 & $162.543^{*}$ \\
\hline Days in other measures & 18.540 & $9.983 * * *$ & 11.194 & $7.249 * * *$ \\
\hline Days with non-professional activities & 2.937 & $4.357 * *$ & 5.503 & 4.488 \\
\hline Days with other status & 388.300 & 391.458 & 403.053 & $384.383 *$ \\
\hline Number of episodes in education & 0.203 & $0.513 * * *$ & 0.435 & 0.451 \\
\hline Number of episodes of self-employment & 0.094 & 0.091 & 0.088 & $0.077^{*}$ \\
\hline $\begin{array}{l}\text { Number of episodes on parental leave, } \\
\text { housewife/househusband }\end{array}$ & 0.253 & $0.265^{*}$ & 0.264 & $0.243^{*}$ \\
\hline Number of episodes in other measures & 0.135 & $0.064 * * *$ & 0.075 & $0.049 * * *$ \\
\hline Days in employment outside Germany & 135.151 & $87.165 * * *$ & 130.882 & $113.647 * *$ \\
\hline Months since first observation in data & 76.089 & 77.236 & 67.850 & $72.024 * * *$ \\
\hline $\begin{array}{l}\text { Duration of current unemployment spell } \\
\text { (days) }\end{array}$ & 800.185 & $633.377 * * *$ & 576.676 & 556.098 \\
\hline Integration course in the past & 0.658 & $0.239 * * *$ & 0.284 & 0.239 \\
\hline \multicolumn{5}{|l|}{ Last occupation } \\
\hline Missing & 0.578 & $0.563 * *$ & 0.575 & $0.530 * * *$ \\
\hline Armed forces occupations & 0.000 & 0.000 & 0.000 & 0.000 \\
\hline Agricultural occupations, forestry & 0.004 & 0.004 & 0.007 & 0.007 \\
\hline Occupations in horticulture floristry & 0.005 & 0.006 & 0.006 & 0.008 \\
\hline $\begin{array}{l}\text { Occupations involving } \\
\text { extraction/production of raw materials }\end{array}$ & 0.001 & 0.001 & 0.001 & 0.002 \\
\hline $\begin{array}{l}\text { Plastics and wood production and } \\
\text { processing }\end{array}$ & 0.006 & 0.007 & 0.009 & 0.010 \\
\hline $\begin{array}{l}\text { Occupations in paper production and } \\
\text { printing, technical media design }\end{array}$ & 0.003 & 0.003 & 0.002 & 0.004 \\
\hline Metal production and processing & 0.013 & $0.019 * * *$ & 0.019 & $0.028 * * *$ \\
\hline Mechanical and automotive engineering & 0.006 & $0.010^{* * *}$ & 0.011 & $0.015^{*}$ \\
\hline Electrical occupations & 0.004 & 0.004 & 0.006 & 0.006 \\
\hline $\begin{array}{l}\text { Occupations in technical development, } \\
\text { production control }\end{array}$ & 0.003 & 0.003 & 0.005 & 0.003 \\
\hline Occupations in textile industry & 0.003 & $0.002 *$ & 0.002 & $0.003 *$ \\
\hline Food production and processing & 0.055 & $0.048 * * *$ & 0.054 & $0.065 * *$ \\
\hline $\begin{array}{l}\text { Occupations in construction planning, } \\
\text { architecture }\end{array}$ & 0.000 & 0.000 & 0.000 & 0.001 \\
\hline Construction occupations & 0.012 & $0.020 * * *$ & 0.015 & $0.023 * * *$ \\
\hline Interior construction occupations & 0.004 & $0.009 * * *$ & 0.010 & 0.008 \\
\hline $\begin{array}{l}\text { Occupations in supply engineering, } \\
\text { buildings }\end{array}$ & 0.003 & $0.006^{* * * *}$ & 0.007 & 0.006 \\
\hline $\begin{array}{l}\text { Occupations in biology, chemistry, } \\
\text { physics, mathematics }\end{array}$ & 0.002 & 0.001 & 0.001 & 0.001 \\
\hline
\end{tabular}


Table 11 (continued)

\begin{tabular}{|c|c|c|c|c|}
\hline & Participants & $\begin{array}{l}\text { Non- } \\
\text { participants }\end{array}$ & $\begin{array}{l}\text { High treatment } \\
\text { intensity } \\
\text { ( } \geq \text { median) }\end{array}$ & $\begin{array}{l}\text { Low treatment } \\
\text { intensity } \\
(<\text { median })\end{array}$ \\
\hline IT occupations & 0.000 & 0.000 & 0.000 & 0.000 \\
\hline Transport and logistics occupations & 0.055 & 0.059 & 0.056 & $0.065^{*}$ \\
\hline Driver & 0.008 & $0.015^{* * *}$ & 0.011 & 0.014 \\
\hline Personal security occupations & 0.006 & $0.008^{* *}$ & 0.006 & 0.007 \\
\hline Cleaning occupations & 0.082 & $0.065^{* * * *}$ & 0.058 & 0.064 \\
\hline Retail occupations & 0.003 & 0.004 & 0.002 & 0.002 \\
\hline Sales occupations & 0.026 & $0.039 * * *$ & 0.030 & 0.035 \\
\hline $\begin{array}{l}\text { Hotel/restaurant occupations, occupations } \\
\text { in tourism }\end{array}$ & 0.049 & $0.041^{* * *}$ & 0.050 & $0.039 * *$ \\
\hline Management occupations & 0.024 & $0.021 *$ & 0.020 & 0.016 \\
\hline Financial service occupations & 0.001 & 0.001 & 0.001 & 0.001 \\
\hline Occupation in law and administration & 0.001 & 0.001 & 0.001 & 0.000 \\
\hline Health care occupations & 0.009 & 0.008 & 0.007 & 0.008 \\
\hline Non-medical health care occupations & 0.005 & $0.008 * * *$ & 0.007 & 0.008 \\
\hline Social occupations & 0.018 & $0.012 * * *$ & 0.012 & 0.012 \\
\hline Instructing and teaching occupations & 0.002 & 0.002 & 0.001 & $0.003^{*}$ \\
\hline Economics, social science, linguistics & 0.001 & 0.001 & 0.000 & 0.000 \\
\hline Occupations in advertising, marketing & 0.005 & 0.005 & 0.005 & $0.002^{* *}$ \\
\hline Product design & 0.000 & 0.001 & 0.000 & 0.000 \\
\hline Artistic occupations & 0.004 & $0.002 * *$ & 0.002 & 0.001 \\
\hline \multicolumn{5}{|l|}{ Skill level last job } \\
\hline Missing & 0.578 & $0.563 * *$ & 0.575 & $0.530 * * *$ \\
\hline Unskilled & 0.196 & $0.180^{* * *}$ & 0.193 & $0.219 * * *$ \\
\hline Skilled & 0.202 & $0.236^{* * * *}$ & 0.212 & $0.231 * *$ \\
\hline Specialist & 0.012 & 0.010 & 0.010 & 0.008 \\
\hline Specialist with highly complex activities & 0.012 & 0.012 & 0.009 & 0.011 \\
\hline \multicolumn{5}{|c|}{ Status before (hypothetical) language training start } \\
\hline $\begin{array}{l}\text { On parental leave, working as } \\
\text { housewife/househusband }\end{array}$ & 0.019 & $0.095^{* * *} *$ & 0.080 & $0.068 * *$ \\
\hline Marginal employment & 0.162 & $0.173 * *$ & 0.168 & 0.168 \\
\hline Job seeking & 0.994 & $0.932 * * *$ & 0.953 & $0.943 * *$ \\
\hline Unemployment benefit receipt & 0.082 & 0.081 & 0.089 & $0.105^{* *}$ \\
\hline Unemployment benefit II receipt & 0.932 & $0.841^{* * *}$ & 0.844 & $0.822 * * *$ \\
\hline ALMP measure & 0.068 & $0.096^{* * *}$ & 0.098 & $0.084 * *$ \\
\hline Education, trainee & 0.010 & $0.114 * * *$ & 0.085 & 0.091 \\
\hline Self-employment & 0.004 & $0.013^{* * * *}$ & 0.010 & 0.009 \\
\hline Employment & 0.015 & $0.050 * * *$ & 0.045 & $0.052 *$ \\
\hline \multicolumn{5}{|l|}{ Regional-level variables } \\
\hline Unemployment rate foreign-born & 19.495 & $18.654 * * *$ & 16.728 & $15.652 * * *$ \\
\hline
\end{tabular}


Table 11 (continued)

\begin{tabular}{|c|c|c|c|c|}
\hline & Participants & $\begin{array}{l}\text { Non- } \\
\text { participants }\end{array}$ & $\begin{array}{l}\text { High treatment } \\
\text { intensity } \\
(\geq \text { median) }\end{array}$ & $\begin{array}{l}\text { Low treatment } \\
\text { intensity } \\
(<\text { median })\end{array}$ \\
\hline Unemployment rate native-born & 8.849 & $8.220 * * *$ & 7.570 & $6.769 * * *$ \\
\hline $\begin{array}{l}\text { Share of foreign-born among } \\
\text { unemployed }\end{array}$ & 0.341 & $0.357 * * *$ & 0.200 & $0.254 * * *$ \\
\hline Share of foreign-born in labor force & 0.158 & $0.162 * * *$ & 0.091 & $0.111 * * *$ \\
\hline Share of women among foreign-born & 0.505 & $0.502 * * *$ & 0.504 & $0.500 * * *$ \\
\hline Share of foreign-born age $25-29$ & 0.146 & $0.144 * * *$ & 0.144 & $0.142 * * *$ \\
\hline Share of foreign-born age $30-34$ & 0.156 & $0.155^{* * *}$ & 0.153 & 0.153 \\
\hline Share of foreign-born age $35-39$ & 0.141 & $0.140 * * *$ & 0.143 & $0.140 * * *$ \\
\hline Share of foreign-born age $40-44$ & 0.115 & 0.115 & 0.116 & $0.114 * * *$ \\
\hline Share of foreign-born age $44-49$ & 0.088 & $0.089 * * *$ & 0.090 & 0.090 \\
\hline Share of foreign-born age 50 and older & 0.122 & $0.124 * * *$ & 0.130 & 0.131 \\
\hline Share of low-skilled among foreign-born & 0.560 & $0.567 * * *$ & 0.539 & $0.566^{* * * *}$ \\
\hline Share of foreign-born from EU countries & 0.263 & 0.264 & 0.280 & $0.287^{*}$ \\
\hline Share of foreign-born from Turkey & 0.262 & $0.267 * * *$ & 0.205 & $0.245^{* * *}$ \\
\hline Share of foreign-born from Russia & 0.043 & $0.041^{* * *}$ & 0.065 & $0.049 * * *$ \\
\hline $\begin{array}{l}\text { Share of foreign-born from other } \\
\text { European countries }\end{array}$ & 0.112 & $0.114^{* * * *}$ & 0.123 & 0.121 \\
\hline Share of foreign-born from North Africa & 0.035 & $0.037 * * *$ & 0.029 & $0.031 * *$ \\
\hline $\begin{array}{l}\text { Share of foreign-born from other African } \\
\text { countries }\end{array}$ & 0.044 & 0.045 & 0.037 & 0.037 \\
\hline $\begin{array}{l}\text { Share of foreign-born from Near/Middle } \\
\text { East }\end{array}$ & 0.163 & $0.165^{*}$ & 0.164 & $0.160^{*}$ \\
\hline $\begin{array}{l}\text { Share of foreign-born from other Asian } \\
\text { countries }\end{array}$ & 0.059 & $0.053 * * *$ & 0.083 & $0.060 * * *$ \\
\hline $\begin{array}{l}\text { Share of foreign-born from America, } \\
\text { Australia }\end{array}$ & 0.019 & $0.017 * * *$ & 0.022 & $0.017 * * *$ \\
\hline Number of unemployed per vacancy & 7.479 & $6.789 * * *$ & 6.320 & $5.985 * * *$ \\
\hline $\begin{array}{l}\text { Share of unemployed entering ALMP } \\
\text { programs }\end{array}$ & 0.060 & $0.062^{* * *}$ & 0.062 & 0.062 \\
\hline \multicolumn{5}{|c|}{ Intensities of ALMP programs for foreign-born } \\
\hline Placement budget & 0.207 & $0.211^{*}$ & 0.301 & $0.264 * * *$ \\
\hline $\begin{array}{l}\text { Activation/integration measures } \\
\text { (provider) }\end{array}$ & 0.038 & $0.039 * * *$ & 0.057 & $0.050 * * *$ \\
\hline $\begin{array}{l}\text { Activation/integration measures } \\
\text { (employer) }\end{array}$ & 0.191 & $0.203 * * *$ & 0.186 & 0.193 \\
\hline Training & 0.045 & $0.043^{* * *}$ & 0.047 & $0.037 * * *$ \\
\hline Wage subsidies & 0.016 & $0.015 * *$ & 0.020 & $0.017 * * *$ \\
\hline Job creation scheme & 0.039 & $0.038 * *$ & 0.042 & $0.035 * * *$ \\
\hline \multicolumn{5}{|l|}{ Share of working population in } \\
\hline Agriculture and forestry & 0.024 & $0.019^{* * *}$ & 0.022 & $0.018 * * *$ \\
\hline
\end{tabular}


Table 11 (continued)

\begin{tabular}{|c|c|c|c|c|}
\hline & Participants & $\begin{array}{l}\text { Non- } \\
\text { participants }\end{array}$ & $\begin{array}{l}\text { High treatment } \\
\text { intensity } \\
\text { ( } \geq \text { median) }\end{array}$ & $\begin{array}{l}\text { Low treatment } \\
\text { intensity } \\
(<\text { median })\end{array}$ \\
\hline Production industry & 0.224 & $0.207 * * *$ & 0.210 & $0.201 * * *$ \\
\hline Manufacturing & 0.210 & $0.192 * * *$ & 0.197 & $0.187^{* * * *}$ \\
\hline Construction & 0.065 & $0.059 * * *$ & 0.066 & $0.060 * * *$ \\
\hline Trade, transport, catering industry & 0.288 & $0.279 * * *$ & 0.260 & 0.259 \\
\hline Financial sector & 0.227 & $0.213 * * *$ & 0.170 & $0.157 * * *$ \\
\hline Public sector & 0.357 & $0.340 * * *$ & 0.333 & $0.312 * * *$ \\
\hline GDP per capita & $42,257.76$ & $43,025.41 * * *$ & $36,697.863$ & $36,490.527$ \\
\hline Population density & 2082.819 & $1784.332 * * *$ & 1081.712 & $834.608 * * *$ \\
\hline \multicolumn{5}{|l|}{ Federal state } \\
\hline Schleswig-Holstein & 0.028 & $0.031^{*}$ & 0.053 & 0.042 \\
\hline Hamburg & 0.042 & 0.046 & 0.009 & 0.006 \\
\hline Lower Saxony & 0.060 & $0.082^{* * *}$ & 0.095 & $0.117 *$ \\
\hline Bremen & 0.017 & $0.022 * * *$ & 0.003 & $0.014 * * *$ \\
\hline North-Rhine-Westphalia & 0.276 & $0.323 * * *$ & 0.122 & $0.259 * * *$ \\
\hline Hesse & 0.054 & $0.070^{* * * *}$ & 0.045 & $0.067 * * *$ \\
\hline Rhineland-Palatinate & 0.039 & $0.043 *$ & 0.074 & 0.073 \\
\hline Baden-Württemberg & 0.073 & $0.103 * * *$ & 0.089 & $0.165^{* * * *}$ \\
\hline Bavaria & 0.097 & 0.095 & 0.194 & $0.152 * * *$ \\
\hline Saarland & 0.011 & 0.010 & 0.007 & $0.021 * * *$ \\
\hline Berlin & 0.236 & $0.120 * * *$ & 0.102 & $0.004 * * *$ \\
\hline Brandenburg & 0.015 & $0.008 * * *$ & 0.050 & $0.020 * * *$ \\
\hline Mecklenburg-Vorpommern & 0.010 & $0.007 * * *$ & 0.039 & $0.013 * * *$ \\
\hline Saxony & 0.028 & $0.021 * * *$ & 0.047 & $0.017^{* * * *}$ \\
\hline Saxony-Anhalt & 0.005 & $0.008 * * *$ & 0.020 & 0.013 \\
\hline Thuringia & 0.009 & 0.008 & 0.049 & $0.016^{* * * *}$ \\
\hline Lagged language training intensity & 0.010 & $0.007 * * *$ & 0.012 & 0.005 \\
\hline$N$ & 8968 & 24,463 & 1353 & 1353 \\
\hline
\end{tabular}

Note: $* / * * / * * *$ indicate significant difference at the $10 \% / 5 \% / 1 \%$ level between participants and nonparticipants or between monthly job center observations with high $(\geq$ median $=0.0053)$ and low treatment intensity $(<$ median $=0.0052)$ 


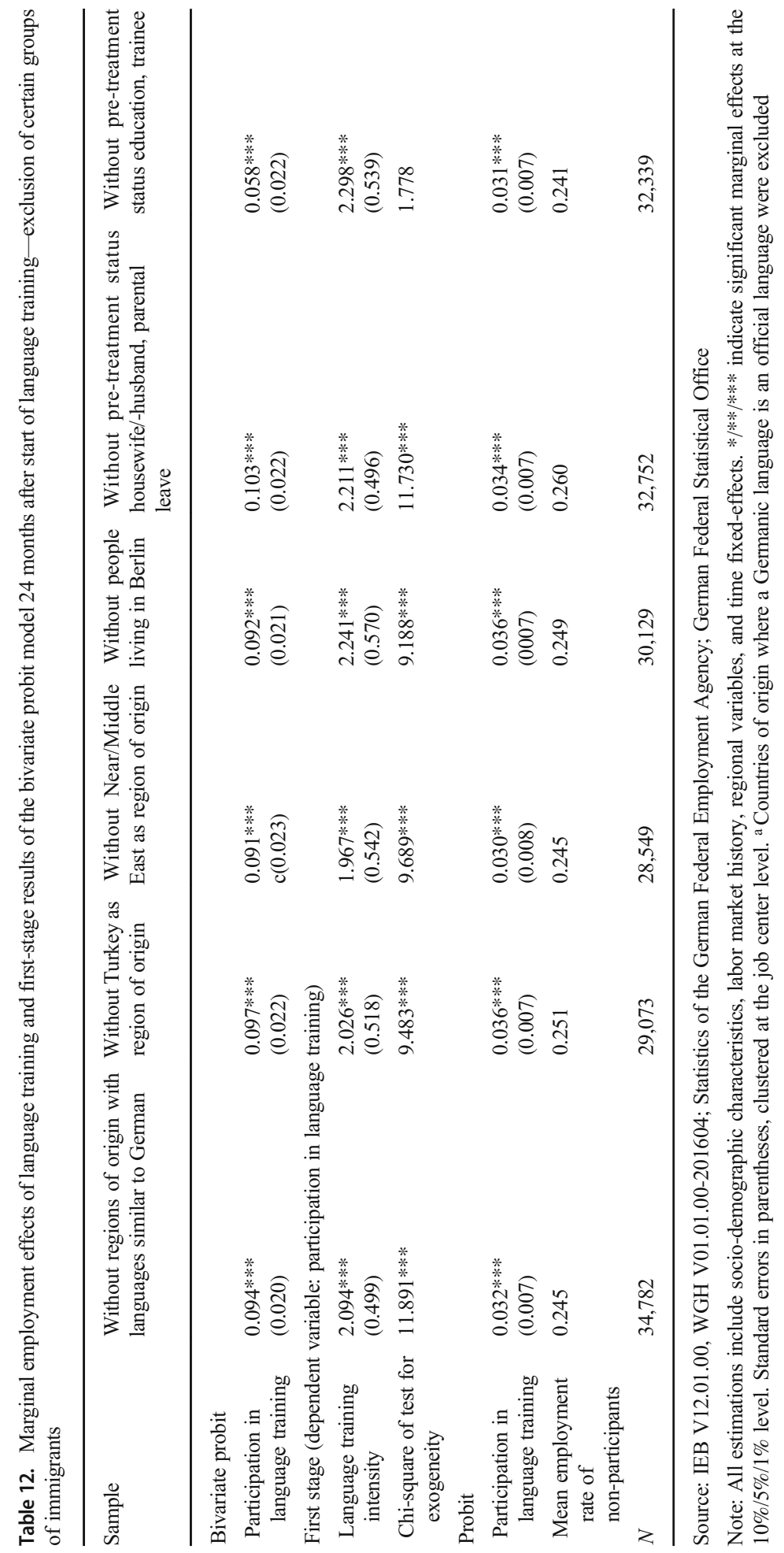


Acknowledgements I thank participants at the EALE Conference in Lyon, at the 4th LEER Workshop on Education Economics in Leuven and at the Workshop on Microeconomics in Lüneburg for many useful comments. I am very grateful for the constructive comments from four reviewers and the editor, Klaus F. Zimmermann. Special thanks go to the DIM department of the Institute for Employment Research (IAB) for providing the data.

Funding Open Access funding enabled and organized by Projekt DEAL.

\section{Declarations}

Conflict of interest The author declares no competing interests.

Open Access This article is licensed under a Creative Commons Attribution 4.0 International License, which permits use, sharing, adaptation, distribution and reproduction in any medium or format, as long as you give appropriate credit to the original author(s) and the source, provide a link to the Creative Commons licence, and indicate if changes were made. The images or other third party material in this article are included in the article's Creative Commons licence, unless indicated otherwise in a credit line to the material. If material is not included in the article's Creative Commons licence and your intended use is not permitted by statutory regulation or exceeds the permitted use, you will need to obtain permission directly from the copyright holder. To view a copy of this licence, visit http://creativecommons.org/licenses/by/4.0/.

\section{References}

Åslund O, Engdahl M (2018) The value of earning for learning: performance bonuses in immigrant language training. Econ Educ Rev 62:192-204

Brücker H, Rother N, Schupp J (eds.); Babka von Gostomski C, Böhm A, Brücker H, Fendel T, Friedrich M, Giesselmann M, Holst E, Kosyakova Y, Kroh M, Liebau E, Richter D, Romiti A, Rother N, Schacht D, Scheible JA, Schmelzer P, Schupp J, Siegert M, Sirries S, Trübswetter P, Vallizadeh E (2016) IABBAMF-SOEP-Befragung von Geflüchteten: Überblick und erste Ergebnisse. IAB-Forschungsbericht 14/ 2016, Nuremberg, Germany

Bleakley H, Chin A (2004) Language skills and earnings: evidence from childhood immigrants. Rev Econ Stat 86(2):481-496

Boockmann B, Thomsen SL, Walter T (2014) Intensifying the use of benefit sanctions: an effective tool to increase employment? IZA J Labor Policy 3(21):1-19

Budría S, Swedberg P (2015) The impact of language proficiency on immigrants' earnings in Spain. Revista de Economía Aplicada 23(67):63-91

BAMF (2013) Berufsbezogene Deutschförderung - Das ESF-BAMF-Programm. Bundesamt für Migration und Flüchtlinge, Nuremberg

BAMF (2017) Bericht zur Integrationskursgeschäftsstatistik für das Jahr 2016. Bundesamt für Migration und Flüchtlinge, Nuremberg

Butschek S, Walter T (2014) What active labour market programmes work for immigrants in Europe? A metaanalysis of the evaluation literature. IZA J Dev Migr 3:48

Caliendo M, Künn S, Mahlstedt R (2017) The return to labor market mobility: an evaluation of relocation assistance for the unemployed. J Public Econ 148:136-151

Chiburis RC, Dasb J, Lokshin M (2012) A practical comparison of the bivariate probit and linear IV estimators. Econ Lett 117:762-766

Chiswick BR (1998) Hebrew language usage: determinants and effects on earnings in Israel. J Popul Econ 11(2):253-271

Chiswick BR, Miller PW (1995) The endogeneity between language and earnings: international analyses. J Labor Econ 13(2):246-288

Chiswick BR, Miller PW (2014) International migration and the economics of language. In: Miller PW (ed) Chiswick BR. Elsevier, Handbook of the economics of immigration, pp 211-269 
Clausen J, Heinesen E, Hummelgaard H, Husted L, Rosholm M (2009) The effect of integration policies on the time until regular employment of newly arrived immigrants: evidence from Denmark. Labour Econ 16:409-417

Dauth C (2020) Regional discontinuities and the effectiveness of further training subsidies for low-skilled employees. Ind Labor Relat Rev 73(5):1147-1184

Dean D, Pepper J, Schmidt R, Stern S (2015) The effects of vocational rehabilitation for people with cognitive impairments. Int Econ Rev 56(2):399-426

Di Paolo A, Raymond JL (2012) Language knowledge and earnings in Catalonia. J Appl Econ 15(1):89-118

Dorner M, Heinig J, Jacobebbinghaus P, Seth S (2010) The sample of integrated labour market biographies. Schmollers Jahr 130(4):599-608

Dustmann C (1994) Speaking fluency, writing fluency and earnings of migrants. J Popul Econ 7(2):133-156

Dustmann C, Fabbri F (2003) Language proficiency and labour market performance of immigrants in the UK. Econ J 113(489):695-717

Dustmann C, van Soest A (2001) Language fluency and earnings: estimations with misspecified indicators. Rev Econ Stat 83(4):663-674

Dustmann C, van Soest A (2002) Language and the earnings of immigrants. Ind Labor Relat Rev 55(3):473492

Eppel R (2017) The effects of a job-creation scheme: evidence from regional variation in program capacities. Ind Relat 56(1):161-190

Ferrer A, Green DA, Riddell WC (2006) The effect of literacy on immigrant earnings. J Hum Resour 41(2): 380-410

Frölich M, Lechner M (2010) Exploiting regional treatment intensity for the evaluation of labor market policies. J Am Stat Assoc 105(491):1014-1029

Hayfron J (2001) Language training, language proficiency and earnings of immigrants in Norway. Appl Econ 33:1971-1979

Imbens G, Angrist J (1994) Identification and estimation of local average treatment effects. Econometrica 62: 467-475

Lechner M, Wunsch C, and Scioch P (2013) Do firms benefit from active labor market policies? IZA Discussion Papers No. 7614

Lochmann A, Rapoport H, Speciale B (2019) The effect of language training on immigrants' economic integration: empirical evidence from France. Eur Econ Rev 113:265-296

Markussen S, Roed K (2014) The impacts of vocational rehabilitation. Labour Econ 31:1-13

Miranda A, Zhu Y (2013) English deficiency and the native immigrant wage gap. Econ Lett 118(1):38-41

OECD (2016) OECD Factbook 2015-2016. OECD Publishing, OECD Paris

OECD (2017) OECD international migration outlook 2017. OECD Publishing, OECD Paris

Rinne U (2013) The evaluation of immigration policies. In: Zimmermann KF (ed) Constant AF. Edward Elgar Publishing, International handbook on the economics of migration, pp 530-551

Sarvimäki M, Hämäläinen K (2016) Integrating immigrants: the impact of restructuring ALMP. J Labor Econ 34(2):479-508

Walter T, Bonin H, Butschek S, Schütz H, Schröder H, Knerr P, Steinwede J, Thomsen SL (2014) Evaluation „Programm zur berufsbezogenen Sprachförderung für Personen mit Migrationshintergrund (ESF-BAMFProgramm)“. Abschlussbericht im Auftrag des Bundesministeriums für Arbeit und Soziales. Bonn, Germany

Yao Y, van Ours JC (2015) Language skills and labor market performance of immigrants in the Netherlands. Labour Econ 34:76-85

Publisher's note Springer Nature remains neutral with regard to jurisdictional claims in published maps and institutional affiliations. 